\section{KISIM: GEÇMIŞTEN GÜNÜMÜZE SEYYAHLAR VE SEYAHATNAMELERIN TASNIFINE DAIR BIR DENEME-2}

Yazı dizimizin bu ikinci yazısında Orta Çă̆'daki seyyahları konu edineceğiz. Seyyahlara geçmeden önce Orta Çă̆'da özellikle Avrupa'da seyahati şekillendiren bazı hususları aydınlatmaya çalışacağız.

Ulaşım ve iletişim olanaklarının günden güne daha geliştiği 21. yüzyıldan geriye dönüp bakıldığında, Orta Çă̆'da Avrupa ve dünyanın geri kalanında yaşayan insanların çevrelerindeki dünya hakkında fazla bilgi sahibi olmadıklarını düşünmek büyük bir kolaycılıktır. Orta Çağ'1 yaşayan Avrupalılar aslında sınırlarının ötesindeki topraklarla derinden meşguldürler. Çoğu zaman, bu etkileşim, ilk elden deneyimden ziyade edebiyat tarihinden daha fazla etkilenen metinlerde ve haritalarda yer alarak, gerçek olmaktan daha yaratıcı bile olabilmektedir. Orta Çağ'ın kâşifleri ve tüccarları, tahmin edilenden çok daha uzaklara gitmişlerdir. Gerçekleştirdikleri seyahatlerle çeşitli kültürel etkileri de beraberlerinde getirmişlerdir.

Orta Çă̆'da bazı insanların yerel pazardan daha uzağa gitmediği ve seyahat etme imkanına sahip olmadığı doğrudur. Örneğin villeins (köylüler), lordlarına bağlıydı ve onun izni olmadan köylerinden ayrılamazlardı, ancak özgür adamlar istedikleri yere gidebilirlerdi. Orta Çă̆'da sıradan insanlar için seyahat etmenin en yaygın nedenleri bir türbeyi ziyaret etmek veya savaşmaktı. Birçoğu yaşadığı yere oldukça yakın yerel bir kiliseyi ziyaret etmekten hoşnuttu. Özellikle İngiltere'de, ülke sınırları içerisinde Walsingham ve Canterbury gibi daha uzak yerlere gitmeye cesaret edenler oldu. İmkân sahibi kimseler, daha uzaklara, yurtdışına Compostela, Roma veya Kudüs'e gitti. Kilise cemaati için hacca gitmek olağan bir aktiviteydi. Turizm tarihçilerine göre, kafile halinde ilerleyen hacılar zamanlarının turistleriydi. Bu açıdan hac kafileleri inanç turizminin belki de ilk öncüllerindendi.

Orta Çă̆'da ordular da seyahat etti. Örneğin Ingiltere'de yerel bir toplanma yerinde bir araya gelen askerler daha sonra İskoçlarla savaşmak için kuzeye ya da Fransızlarla savaşmak için gü- neye gitmek amacıyla ordunun geri kalanına katılmak üzere yola çıkmaktaydılar. Bazı ülkelerde yönetim biçim ve organizasyonu da Orta Çă̆'ın seyahat alışkanlıklarında belirleyici olmuştur. Örneğin, İngiltere'de parlamentonun toplanması demek, ülkenin farklı kesimlerinden gelen soylular, kıdemli din adamları, şövalyeler ve kasabalıların, başka bir deyişle yaklaşık dört yüz adam ve bunların maiyeti ve hizmetçilerinin yollarda ilerlemesi demekti. Onlara ev sahipliği yapmak yol üzerinde bulunan bazı küçük kasabalar için büyük bir yüktü. Bu bakımdan İngilizler, parlamentonun, kalacak yer bulmanın daha kolay olduğu Westminster'de toplanmasını savundu. Bu bakımdan, birçok soylu ve piskopos Londra'da kendilerine konaklama yerleri satın almak durumunda kaldı. İngiltere'de yollar boyunca ilerleyenler arasında din adamları da önemli bir yer tutuyordu. Başpiskoposlar ve piskoposlar, Orta Çă̆'da bir ara, papanın ikamet ettiği Fransa'daki Avignon'a gidip geldiler ve piskoposlukları sınırı içindeki yerleşim yerlerini de ziyaret ettiler. İnsanların kendi kiliselerinde işitemeyecekleri şeyleri öğreten birçok gezgin vaiz de vardı.

Orta Çă̆'da seyahat etmek hafife alınacak, sıradan bir uğraş değildi. Uzun mesafeli bir yolculuk kapsamlı ve ciddi ön hazırlık ve yol arkadaşları gerektiriyordu. Tek başına seyahat etmek güvenli değildi. Yollar haydutlar tarafından kuşatılabilirdi. Bunlar genellikle, İskoçlara ve Fransızlara karşı savaşta yaşanan durgunluk sırasında ev ya da memleketlerine geri dönmeyen ve başka bir iş tutmayan askerlerdi. Orta Çă̆'da haritacılık yaygın olmadığı gibi mevcut haritaların amacı da bir gezgine yardım etmek değildi. Bu yüzden insanlar, haritalar yerine seyahat planlarına başvurmak zorunda kalmıştır. Bu planlarda bir güzergâh olurdu. Güzergâh, başlangıç noktası ile varış noktası arasındaki yerleri listelerdi. En azından rotanın ilk kısmında biraz deneyimi olan biriyle seyahat etmek büyük bir şanstı. Böyle bir yoldaşı olmayan yolcu, bulunduğu kasabanın sakinlerine bir sonraki yere nasıl gideceğini sormak zorundaydı. Bazen nehirler yolculara yardımcı olurdu. Büyük bir nehri takip eden yolcu, er geç kendisini pazar kurulan büyük bir kasabada bulabilirdi. 
Manastırlar ve hacıların ve diğer yolcuların geceyi geçirebilecekleri bakımevleri veya misafirhaneler ve hanlar 14. yüzyılın ortalarında kara veba ortaya çıkana kadar yavaş yavaş arttı. Soylular aynı zamanda kendi sınıflarından olanlardan konukseverlik isteyebilirlerdi. Çoğu zaman gelecek gece için kalacak yerlerini ayarlamaları için önceden haberciler gönderirlerdi. Kapalı konaklamanın olmadığı veya grubun kapalı tesisler için çok büyük olduğu yerlerde, gezginler açık havada uyuyabilirdi. Bununla birlikte, haydutlarm yarattığı tehlikeler göz önüne alındığında, bireysel gezginler çoğunlukla korunmak için bir gruba katılmaya çalışırlardı. Chaucer'ın Canterbury Masalları'nda bir araya gelip yola çıkan hacılar bu duruma iyi bir örnektir.

\section{Orta Çağ'ın Seyyahları}

Orta Çă̆'da Seyahatleri Yönlendiren Nedenler: Çoğunlukla karanlıkla anılsa da Orta Çağ hareket halinde bir dünyaydı. Örneğin, kırsal kesimlerdeki gençler, kendilerine sosyal statüsü yüksek bir eş ya da daha iyi bir iş bulabilmek için şehirlere göç etme yolunu seçerlerdi. Gerçekten de modern öncesi zamanlarda şehirlerin artan ölüm oranı, onları "nüfus batağı" haline getirdiğinden, şehir büyümesi mutlaka yüksek düzeyde göçlerin bir neticesiydi. Madenciler ve değirmenciler gibi çağın sanayisini yönlendirenler de yer değiştirme konusunda dikkat çekici örneklerin başında gelmekteydi. Almanya Schwarzwald'daki madenciler, ekonomik, politik veya başka herhangi bir nedenle yeni madenlere gidip çalışabilme özgürlügüne sahipti. İngiltere'deki değirmenciler gittikleri yeni yerlerde sürekli talep görüyordu. Orta Çağ'da Doğu ve Batı'daki seyahatler her ne kadar farklı kimlikte insanların seyahatleri olsa da insanların benzer ihtiyaçlara sahip oldukları düşünüldüğünde seyahatleri tetikleyen faktörler üç aşağı beş yukarı benzerdi.

Orta Çă̆'da seyahat, yüksek mevkileri işgal eden insanlar arasında çok daha yaygındı. Krallar sıklıkla yurt içi seyahatler gerçekleştirirlerdi. Haberleri etkin bir şekilde duyuracak medyanın henüz ortaya çıkmadığ 1 bir çağda, bir kralın zaman zaman krallığının her yerinde kendini göstermesi, yerel yetkilileri desteklemesi ve ayrıca insanlara hükümdarın kim olduğunu hatırlatması gerekiyordu. Bu türden seyahatlerde kral, ailesi ve maiyetiyle birlikte yolculuk yapardı. Krallar kendi korumasındaki soyluları da ziyaret ederlerdi. Gerçi bu türden ziyaretler her zaman hoş karşılanmıyordu. Çünkü kalabalık maiyetiyle birlikte gelen kralı ağırlamak ev sahibine her zaman pahalıya mal oluyordu. Bu açıdan kral herhangi bir yerde üç haftadan fazla kalamazdı. Soyluların da genellikle ülkenin dört bir yanına dağılmış ve zaman zaman ziyaret edebilecekleri mülkleri vardı. Onlar da mülklerine seyahatler gerçekleştirebilirdi.

Orta Çă̆'da din amaciyla yapılan seyahatler oldukça yaygındı. Misyonerler, genellikle gemiyle, Kuzey Afrika'ya veya Anadolu'ya kadar seyahat ettiler. Bununla birlikte, yalnızca birkaçı insanlara vaaz etmeyi başarabildi ve güvenli bir şekilde geri dönebildi. Birçoğu farklı nedenlerle hastalandı ya da çeşitli kazalardan dolayı yolculuk sırasında hayatını kaybetti. Orta Çağ'da hac, seyahat etmenin çok özel bir şekliydi. Orta Çağ'da Hristiyan hacılar için en popüler üç yer Roma, Santiago de Compostela ve Kudüs'tü. Compostela'ya giden yol, Cluny (Kluni) Tarikatı tarafından organize edildi ve yol boyunca manastırlar hacı adaylarına yiyecek ve barınak sağladı. Hac yolları boyunca ve kutsal yerlerin çevresinde kurulan çeşitli işletmeler hacıların yemek, barınma ve ulaşım ihtiyaçlarını karşıladı. Ayrıca bu süreçte modern rehber kitapların prototipi olan özel rehber kitaplar da ortaya çıkmaya başladı. Bu rehber kitaplarda yol tarif ediliyor ve hacilara yol boyunca nelerle karşılaşacakları etraflıca anlatılıyordu. Örneğin, bir rehber, hacılara yolda karşılaşacakları bir yer hakkında şöyle diyordu: "Burası 1ssız bir bölge; ekmek, şarap, et, balık, su veya kaynak yok; burada köyler de nadirdir." Geoffrey Chaucer'in Canterbury Masalları'na bakıldığında her türden insanın hacca gittiğini söylemek mümkündür. Bir şövalye, bir değirmenci, bir aşçı, bir tüccarın karısı, bir doktor, bazı rahibeler ve diğer çeşitli karakterler muhtemel hacı adaylarıdır. Toprağa bağlı serfler dışında, köylülerden soylulara kadar hemen hemen her statüden insanlar Orta Çağ boyunca hacca gitti. Ayrıca hacıların kafile halinde seyahat ettiklerini söylemek de gereklidir. Hacıların çoğu bir grup arkadaş, akraba, komşu veya 
yabanciyla seyahat etti. Bu, hirsızlar ya da haydutlar tarafından saldırıya uğramamak için etkili bir yöntemdi.

Haçlı Seferleri, yarı sefer ve yarı hac olduğu için, seferlere katılan Avrupalılar/Hristiyanlar açısından hacdan daha özel bir seyahat anlamina geliyorlardı. Seferler, Kudüs'ü de kapsayan kutsal toprakları Müslümanların elinden geri almayı amaçlıyordu. Çeşitli sınıflardan insanlar Haçlı Seferlerine şöhret ve servet kazanmak, günahlarını bağışlatmak ya da sadece Kudüs'e giden Hristiyan hacıları korumak ve Hristiyan ülkesini Kudüs topraklarında yeniden inşa etmek gibi çeşitli amaçlarla katılmışlardır. Haçlı Seferlerine bu kadar çok insan katıldığı ve seferler çok uzun sürdüğü için Haçlıların seyahat ederken kullandıkları ulaşım araçları ve yolları çok çeşitlidir. Haçlı Seferleri, başlangıçtaki hedefi olan Kudüs'ü geri alma konusunda başarısız olmasına rağmen, sonuç olarak diğer kültürleri Avrupa'ya getirme bakımından Avrupa'nın tarihi seyrinin gelişimine önemli katkılar sağlamıştır.

Bir savaşta herhangi bir görev nedeniyle yer almak, o kişi için bazen ülke sınırları içinde, çoğu zaman ülke sınırları ötesinde seyahat etmeyi gerektiriyordu. Örneğin Fransızlarla yaptıkları Yüzyıl Savaşları (1337-1453) içerisinde yer alan Crecy (1346) ve Agincourt (1415) muharebelerinde savaşan İngiliz askerleri denizi geçmek zorunda kaldılar. Bu tür bir seyahat, hem ülke dışına çıkışı, uzun yıllar sonra savaştan eve dönüşü bir arada içeriyordu. İnsanların savaşlar dolayısıyla seyahatlere çıkmalarının başlıca nedeni, bir başkasının, örneğin papanın veya kralın, onların savaşmasını istemesidir. Ancak savaşçıların ganimetten pay alma veya ün kazanma arzusu gibi daha pek çok durum savaş gezginliğinin sebepleri arasindaydi.

Tarihin her döneminde olduğu gibi Orta Çağ'da da ticaret için seyahat oldukça yaygındı. Alacak ya da satacak mal bulmak için sık sık seyahate çıkan tüccarlar, duruma göre hem deniz hem de kara yollarını tercih edebiliyordu. Avrupalı tüccarlar Afrika'dan köle, şeker, altın, fildişi ve değerli taşlar; Asya'dan ipek, kürk, halı gibi değerli eşyalar ile biber ve tarçın gibi değerli baharatlar getirdiler. Kutsal topraklardan dönen Haçlılar, pirinç, pamuk, parfüm, ayna, limon ve kavun gibi egzotik mallarla ülkelerine ulaştılar. Ayrıca Avrupa'nın ürettiği şarap, tuz, yün, bakır, balık ve kerestenin pazarlanması da oldukça önemliydi. Tüccarlar ve denizciler satacak bir şeyler bulmak için büyük riskler aldılar. Bunlar için, kötü hava koşulları ve korsanlar sürekli tehditlerdi. Bir mürettebat gemi kazası geçirdiyse kurtarılma umutları çok azdı, çünkü birçok ülkede, kazaya uğrayan bir gemiden kurtarılan tüm ganimetin, hayatta kalanlar olmadığı sürece, bulanların mülkü olduğunu söyleyen yasalar vardı. Tüccarlar, çoğunlukla, eski Roma toprakları üzerinde ortaya çıkan ve bir pazar kurulan kasabalar arasinda seyahat ettiler. Pazarlar genellikle ibadetten sonra kilisenin etrafında kurulurdu. Bu nedenle yollar hafta sonları hem tüccarlar hem de pazara bir şeyler almak için gelen insanlarla dolu olurdu.

Orta Çă̆'da kalfalıktan ustalığa geçmek ve farklı atölyelerde deneyim kazanmak için bir kasabadan diğerine geçmek, Avrupalı bir usta adayının eğitiminin önemli bir parçasıydı. Almanya'da Orta Çağ boyunca ve sonrasında genç kalfaların çıraklık eğitimlerinden sonra birkaç yıllığına seyahat etmeleri ve tecrübelerini sürdürmek ve becerilerini derinleştirmek için loncanın diğer ustalarıyla uzak yerlere gitmeleri yaygındı.

Seyahat Edenlerin Nitelikleri: Nereye giderseniz gidin, Orta Çağ'da kasabanızın veya köyünüzün s1nırlarının ötesine seyahat etmek adeta bir macera ya da bir çeşit kar fırtınasıydı: Haberciler, elçiler, hacılar, tüccarlar, maceraperestler, vaizler, misyonerler, akademisyenler, askerler, kâşifler bu fırtınanın içerisindeki küçük kar tanecikleriydi. Bu fırtınanın bir resmi çizilebilseydi, yabancı bir dinin hâkim olduğu topraklardaki paralı askerler, haclarını tamamlamaya kararlı fakir insanlar için yiyecek ve barınak sağlayan Müslüman soylu kadınlar, özellikle zorlu kraliyet hastalıklarını çözmek için iş birliği yapan farklı üniversitelerde eğitim almış doktorlar manzaranın içerisine serpiştirilmiş önemli ve romantik figürler olurdu. Romantik olurdu olmasına ama bu romantizmi bozan önemli bir faktör vardı: Orta Çă̆'da karayolu seyahati temelde korkunçtu. 
Yollarda ilerleyen Avrupalılar içerisinde tüccarlar, göçmenler, postacılar, askeri ve dini şahsiyetler, soylular, vergi tahsildarları, zanaatkârlar, fahişeler, sanatçılar, âşıklar, öğrenciler, aydınlar, serseriler, dilenciler de önemli bir yer tutardı. Çiftçiler ürünlerini panayırlara ve yerel pazarlara satmak için seyahat eder, genellikle en yakın köye kısa geziler yapardı.

Yolculuklarm Süresi: Bir günde kat edilen mesafe, gün ışığı altında geçen saat sayısına, yılın zamanına, hava durumuna ve bir sonraki hanın nerede olduğuna bağlıydı. Bir sonraki han sekiz kilometre uzaktaysa ve kışın ikindi vaktiyse, oraya ulaşmaya çalışmanın pek bir anlamı yoktu. Gezginler ve hayvanlar yemek yiyip dinlenmek zorundaydı ve bu zaman alırdı.

Orta Çağ Avrupa'sında seyahat edenlerin karayolundaki ulaşım araçları atlar, arabalar ve insanların ayaklarıydı. Yürüyerek seyahat etmek açık ara en yaygın olanıydı. Günümüzde İtalyan şehirlerinden Fransiz sahillerine, Toledo'dan Salerno'ya, Paris'ten İstanbul'a yürüyen insanları düşünmek inanılmaz gelebilir. Yürüyen ve acelesi olan biri, iyi koşullarda günde 15 ila 20 mil (yaklaşı $25-32 \mathrm{~km}$.) seyahat edebilirdi. Hava şartları veya yollar kötüyse, bu altı ila sekiz mile (yaklaşık 10-13 km.) kadar gerileyebilirdi. Bununla birlikte, Orta Çăg'ın son demlerinin yaşandığ1 14. yüzyılda Fransız yolcuları inceleyen Marjorie Nice Boyer, bir yolcunun günde yaklaşık 10 saat boyunca 30 mile (yaklaşı $48 \mathrm{~km}$.) kadar yürüyebileceğini ortaya koydu.

Bir araba günde 12 mil (yaklaşık $20 \mathrm{~km}$.) yol kat edebilirdi, bu kış mevsiminde daha az olurdu. Arabalarla, özellikle ticari mallarla ilerlemek hiç şüphesiz seyahat edenleri yavaşlatabilirdi. Örneğin, Brabant Düşesi Margaret, 1297'de tüm giyim koleksiyonunu eşinin malikânesine taşımaya karar verdiğinde, arabanın Londra'dan Ipswich'e kadar ilk 85 kilometreyi kat etmesi on sekiz gün sürdü. Üstelik araba bu hıza ancak beş atla erişebildi. Özellikle erkekler, yaşlı veya hastaysa bir vagona binerdi ve ata binemeyen zengin bir kişi muhtemelen iki atın taşıdığı bir arabada seyahat ederdi.

Atlı gezginler diğer araçlarla ilerleyenlere göre çok daha hızlı yol alabiliyordu. Atlı bir adam, tüm yolculuk boyunca aynı atı kullanmak zorunda olsaydı, günde 20 ila 25 mil (yaklaşık 32$40 \mathrm{~km}$.) seyahat edebilirdi. Zengin adamlar ve memurlar atları değiştirebilir ve günde 30 ila 40 mil (yaklaşık 48-65 km.) yapabilirdi. İşler son derece acil ve yeterli para olduğunda, bir binicinin at değiştirerek daha hızlı gitmesi de mümkündü. Boyer, profesyonel postacılara ait iki vaka örneğinde atlarla bir günde 52 ve 56 mil (yaklaşık 85$90 \mathrm{~km}$.) kat edilebildiğini ortaya koydu. Bir başka kayda göre ise İngiltere Kralı II. Richard, tek bir gecede 70 mil (yaklaşık $112 \mathrm{~km}$.) yol katetmişti. Ne var ki atlı biniciler, bir ya da iki uşakla seyahat etmiş görünüyorlar. Tuhaf olansa biniciler at sürerken uşaklar yürüyerek ilerlemek zorundaydı. Birisi ayrı bir yük atı gerektirecek kadar mal getiriyorsa yanında yürüyen biri de mutlaka olurdu. Bu karma binekli/yürüyen gruplar tek başına ilerleyen yayalardan daha uzağa daha hızlı seyahat etmiş gibi görünüyor.

Mümkün olduğunda, su yoluyla seyahat etmek genellikle daha kolaydı. Büyük nehirler yaygın olarak ulaşımda kullanıldı. Teknelerin dipleri düzdü. Bu da nehirde bugün olduğundan daha fazla seyrüseferin mümkün olduğu anlamına geliyordu. Çoğu mal tekneyle taşındı. Seine, Ren, Loire, Rhone, Moselle ve diğer nehirler Avrupa'nın başlıca nehir yollarıydı. Denizci teknelerinin gidemediği yerlerde, dar draftlı mavnalar kolaylıkla ilerleyebilirdi. Norbert Ohler, Kuzey Denizi'nden Akdeniz'e Ren, Aare ve Rhone nehirleri yoluyla gidilebileceğini ve toplam 1243 milin (yaklaşık 2000 km.) çok azının ulaşıma elverişli olmadığını bildirmektedir. Nehirleri ve akarsuları birbirine bağlamak için kanallar da oluşturulmuştur. Su çok azaldığında, tekne ve yükü taşınır veya sürüklenirdi. Bu teknelerin küçük boyutları göz önüne alındığında, gezginler genellikle geceyi nehir kıyısında geçirirdi. Ohler'e göre bir mavna, Rhone üzerinde Lyon'dan Avignon'a 125 millik (yaklaşı 201 km.) mesafeyi iki ila beş gün içinde gidebilirdi. Hiç şüphesiz, akıntıya karşı gitmek daha zordu. Sonuç olarak, malları suyoluyla göndermek karayoluyla göndermekten çok daha ucuzdu. Şarabı bir arabada karayolundan 50 mil uzağa göndermek, Bordeaux'dan Londra'ya deniz yoluyla yak- 
laşık 1000 mil (yaklaşık 1609 km.) göndermekten daha pahaliya mal oluyordu.

Hava koşullarının uygun olması ve başka türden engeller olmaması halinde Fransa'yı bir baştan diğer başa kat etmek 12 ila 20 gün sürmekteydi. Nehir yolculuklarında hız, akıntıya eşlik ederek ya da akıntıya karşı kürek çekerek seyahat etme durumuna bağlı olarak farklı olabilirdi. Örneğin, Rhone'da Lyon'dan Avignon'a 24 saat süren bir nehir yolculuğu Avignon'dan Lyon'a bir aya kadar sürebilirdi.

Deniz yolculuklarının süresi de farklı etkenlere göre şekillenirdi. Fırtınalar, ters rüzgârlar ve görüş mesafesi gibi pek çok etken yolculuğun süresini etkileyebilirdi. Bununla birlikte, Tunus'tan Mallorca'ya gitmek için iki veya üç gün gerekliydi; Tunus'tan Cenova veya Pisa'ya yedi; bu İtalyan şehirlerinden Mallorca'ya üç ve İskenderiye'den Barselona'ya 14 günde ulaşmak mümkündü. Bunlar ortalama sürelerdi; gerçek zaman, hava durumuna ve mola sayısına bağlı olarak büyük ölçüde değişebilirdi.

Yollar, Araçlar ve Bilgi Kaynakları: Orta Çağ yolları tekdüzelik arz etmemekteydi. Nürnberg gibi şehirler erken bir tarihten itibaren kendi sokaklarinı kesme taşla döşediği gibi, şehirlerin çevresindeki yollar da yağışlı günlerde yoğun trafikte çamura dönüşmemesi için taşlarla döşenebilmişti. Köprülerden ve geçitlerden alınan ücretler, toprak ve taş yolların bakımı için emeğin ödenmesine yardımcı olurdu. Kasabalardan daha uzaktaki yollar, basit levhalarla işaretlenmiş, sahip olunan arazilerin sınırları ile yarı çiğnenmiş doğal bir yoldan başka bir şey değildi. Orta Çă̆ yollarının sorunlu olduğu zamanlar çok olmuştur. Çamur, bu zaman diliminde yolların başlıca handikabıydı. Fransa'da Lille'e çevre yolların önemli bir kısmı 1395-96 kışında sulu bir çamur banyosuna dönüşmüştü ve bu yolda ilerlemek neredeyse imkânsızdı. Bu tip yollarda bazen ekstra ahşap kalaslar getirilerek veya çakıl taşlarıyla atların toynakları için bir yüzey oluşturularak ilerleme sağlanabilirdi.

Kara yolculukları, 12. yüzyıldan itibaren iyileştirilmeye başlayana kadar, ağır hasar görmüş antik Roma yolları üzerinden gerçekleşti. Avrupa'da 14. yüzyılda yayılmaya başlayan yolculuk listele- ri, nadiren de yol haritaları kullanıldı. Sözlü bilgi en çok kullanılan ve en geçerli ve güncel bilgiydi. Gruplar halinde ve ağır yüklerle seyahat etmek yaygındı. Yolcuların kargoları arasında mallar, yiyecek, silahlar, aletler, çadırlar, giysiler, para, belgeler vb. olurdu. Hacılar daha hafif yüklerle seyahat ederdi. Uzun mesafelerde seyahat etmek günümüzde de olduğu gibi pahalıydı. Yolculuğun maliyetini artıran faktörlerin arasında taşıy1cılara, uygun ve şı giysilere, bahşişlere, konaklamaya, yemeğe, veterinerlere vb. yapılan ödemeler belirleyiciydi. Seyahat edenler için şarap, özellikle şehirlerde, bazı güvenli olmayan sulara nazaran tercih edilen bir içecekti.

Orta Çağ'da araba gibi tekerlekli araçlar kısa mesafeler için kullanışlıydı ancak yolların kötü olması nedeniyle uzun yolculuklarda pek kullanılmıyordu. Eyer ve benzeri binim ve koşum takımları çok kullanılırdı. Ulaşımda at, katır veya eşek önemli binek ve yük hayvanlarıydı. Bu hayvanların ulaşımda kullanılması yürümeye bağlı yorgunluğu ortadan kaldırır, daha fazla yük taşımaya imkân verir ve engebeli yollara uyum sağlardı. Hayvanların zorlukla karşılaşmaması için çoğunlukla dörtnala gidilmez, hatta tırıs bile olmamalarına dikkat edilirdi. Bunlar genellikle kiralık hayvanlardı.

Denizden yolculukları belirleyen bir dizi araç söz konusuydu. Yolcular, kıyı kentleri arasındaki uzun yolculuklar için deniz yolunu tercih ederdi. Deniz yolculukları karadan daha hızlı ve daha rahattı. Örneğin Barselona ve Cenova arasında belirli aralıklarla deniz yoluyla seyahat etme imkânı vardı.

Akdeniz'de, açık denizlere girmek yerine, kıyı şeridini kaybetmeden burundan buruna kıyı taş1macılığ kullanılırdı. Bu türden bir deniz ulaşım seçeneği kötü hava koşullarında limanlara sığınmaya izin verir ve gemi kayıplarının önüne geçilmesini sağlardi.

Gemilerin başlıca itici güçleri kadırgalarda kürek ve çağın sonlarına doğru geliştirilen karavellerde yelken ve küreğin karma biçimde kullanımıyd. Yelken, denizin en sakin olduğu yaz aylarında (tercihen Haziran ve Temmuz) kullanılırdı. Güzergâhı korumanın en yaygın yöntemleri, gün boyunca güneşin konumunu ve geceleri yıldızla- 
rı takip etmek ve gemide bulundurulan kuşları serbest bırakmaktı. Geç Orta Çağ'da, daha az mola ile seyrüseferi kolaylaştırmak için Avrupalı denizciler arasında yayılan bazı bilimsel gelişmeler de sağlandı. Bu gelişmelerin esin kaynağı çoğunlukla Müslüman denizcilerdi. Üçgen yelken (12. yüzyıl), pusula (1200 civarında), kıç dümen (13. yüzyıl) ve ilk deniz haritaları (13. yüzyıl) bu süreçte Avrupa denizciliğine eklendi. Usturlab ve kadranın Avrupa denizcileri tarafından kullanılması için 15. yüzyılı beklemek gerekecekti.

Cenevizli ve Venedikli tüccarlar, Uzak Doğu ile doğrudan değil, İpek Yolu'nun gemileri ve kervanları arasında bir köprü görevi gören Anadolu'daki aracılar aracılığıyla ticaret yapıyorlardı. Orta Çağ'ın sonlarında, Akdeniz'deki tek düzenli yolcu servisi, Venedik'ten Kudüs'e her yıl hacılarla dolu yolculuk yapan kadırga aracılığıyla sağlanmaktaydı.

Bugün karayoluyla yaptığımız bazı kıtasal rotalar Orta Çağ'dan itibaren nehir yoluyla yapılabiliyordu. Örrneğin Rhone ve Ebro boyunca, Zaragoza'ya böyle bir yolculuk gerçekleştirmek olasıydı. Nehir ulaşımı geçiş ücreti gerektiriyordu ve esas olarak ticari mallar için kullanılıyordu. Her türlü olumlu ve olumsuz özelliği bir yana, nehir ulaşımı Avrupa kıtası özelinde hem deniz hem de kara rotalarını çok iyi tamamlıyordu. Günümüzde büyük nehirlerin üzerine inşa edilmiş olan barajlar, bugün bu şekilde seyahat edilmesini imkânsız hale getirmektedir.

Konaklama ve Yeme-İçme: Orta Çağ Avrupa'sında, kara yolcuları için sınırlı sayıda han vardı; en önemli yollarda misafirhaneler bulunmaktaydı. Bunlar yoksulların ve hacıların sınırlı bir süre için ağırlandığı ve çeşitli ihtiyaçlarının karşılandı $\breve{g}$, genellikle Kilise ile bağlantılı pansiyonlardı. Gezginlere yiyecek ve konaklama sağlayan özel yerler de vardı. Gezginler manastırda bir gece kalabilse de özellikle hac yollarının yakınında çok fazla hacı olduğu için gezginlere yiyecek ve konaklama sağlamak için pansiyonlar da kurulmuştu. Orta Çağ pansiyonları veya hanları çoğunlukla basit yiyecekler sağlıyordu ve bazen gezginler yatakları paylaşmak zorunda kalıyordu. Ancak hanlar manastırlardan daha "keyifli" olduğu için, bazı seyyahlar ücret öde- mek zorunda kalsalar da hanları manastıra tercih ederlerdi. Ayrıca manastırların olmadığı kasaba ve köylerde de yolcular handa uyumak zorunda kaliyordu.

Kulübelerde ve çiftliklerde yolcuların ağırlanması da yaygın bir uygulamaydı ve hatta bazı ülkelerde zorunluydu. Kutsal Roma Cermen İmparatoru Charlemagne (Şarlman), daha otellerin yıldızlara göre sınıflandırılmasına on asırdan çok fazla bir zaman olduğu bir tarihte, piskoposları fakirler ve zenginler için farklı pansiyonlar kurmaya teşvik etmişti. Bazen yerel halk gezginlerin evlerine girmesine izin verir ve onlara yiyecek ve konaklama sağlardı. Misafirler, ev sahibinin yanına otururlar ve eğer layık görülürlerse, uyumaları için evde kendilerine yer verilirdi. Aksi takdirde, Yahudiler gibi kâfir sayılan misafirlere sofranin en alt sıralarında yer verilerek ahırda yatırılır, hatta eve alınmazlardı. Sürgünlerin de evlerde barınmasına izin verilmezdi, çünkü onlara yiyecek ya da barınma sağlayan herkes cezalandırılırdi.

Gezginler bir gece için uygun çatıyı bulamazlarsa, geceyi yolda kendi imkanlarıyla geçirmek zorunda kalabilirlerdi. Bu tehlikeliydi çünkü haydutlar veya hırsızlar tarafından saldırıya uğrayabilirlerdi. Üstelik o dönemde pek çok insan şeytan, hayalet gibi hurafelere inandığ için geceyi yolda geçirmeyi korkutucu ve güvensiz bulunurdu.

Deniz yolcularının dinlenme olanakları Orta Çağ'da oldukça sınırlı ve berbat bir noktadaydı. Denizle yapılan seyahatlerde, sicaklığın ve pis kokunun dayanılmaz olduğu yerde, güverte altında uyumaktansa köprüde uyumak daha iyiydi. Yolcu üstünü değiştirmek için kıyafet taşımaz, bitlenir ve helalarda dalgalar içeri girerdi.

Yollarda Karşılaşılabilecek Zorluklar: Orta Çă̆'da farklı güzergahlarda ilerleyen yolcuları yol boyunca bekleyen bazı zorluklar da vardı. Karada, olası olaylar şunlardı: Haydutlar tarafından yapılan soygunlar, beklenmedik geçiş ücretleri, atların yorgunluğu, savaşlar, veba gibi salgınlar, kazalar, kırık bir köprü, bir kar fırtınası vb. O günlerde ayakkabılar uzun yürüyüşlere dayanıklı değildi ve pek çok kişi çıplak ayakla seyahat etmek zorunda kalabiliyordu. Hac gibi bazı uzun 
yolculukların uzunluğu ve zorluğu, yolculukta çok sayıda yolcunun hayatını kaybetmesi anlamina geliyordu.

Orta Çağ'da karada seyahat ederken, Roma İmparatorluğu döneminde veya yerel zenginlerin cömertliğiyle döşenen birkaç yol dışında yollar iyi durumda değildi. Yollar kayalıktı, yağmur yağdığında çamurlu, hava güneşliyken toprak dolu olduğu için seyahat etmek çok zaman ve çaba gerektiriyordu. Ana yollar, kendisini ve ordularını krallığın etrafında dolaştırmak için onlara ihtiyaç duyan kralın emriyle çoğunlukla iyi durumda tutuldu. Diğer yollar genellikle çok kötüydü ve beklenmedik bir şekilde kapanabilirdi. Kralın geçtiği karayollarının her iki tarafının da 200 fit (ayak) temizlenmesi gerekiyordu. Bu, haydutlara ve pusu kurma olasılığ olanlara karşı bir önlemdi. Bazen ormandaki yolları göstermek için yol işaretleri vardı, ancak bunlar yolcuları bekleyen haydutlar tarafından kolayca hareket ettirilebilir ve başka yönlere çevrilebilirdi.

Denizde en ciddi tehlikeler korsanlık ve gemi kazalarıydı. Deniz sigortası 15. yüzyıla kadar ortaya çıkmamıştı ve deniz ticaretine katkısına epey bir zaman vard1.

Yolcular için bazı tehlikeler hem karada hem denizde ortaktı. Yerel para birimlerinin varlığı, genellikle içerdiği suiistimalle birlikte sık sık para değiştirmek zorunda kalmak anlamına geliyordu. Yerel önlemlerin çeşitliliği, özellikle tüccarlar için gerçek bir sorun teşkil ediyordu. Geleneklerin yarattığı cehalet, çoğu zaman bir zorluktu; yerel yasalar genellikle yabancıları koruyacak hükümler içermemekteydi. Latince, kuzey Akdeniz kıyılarında, çoğu insan tarafından anlaşılan bir tür ortak dil (lingua franca) olarak kaldı.

Seyahat sırasında karşılaşılan tehlikeleri şu şekilde sıralamak mümkündür: Ormanda yaşayan, gezginlere saldıran ve bazen onları öldüren hırsızlar ve kanun kaçakları vardı. Bu nedenle, yabancılara şüpheyle davranılırdı, böylece herhangi bir gezgin yol boyunca karşılaştıkları biri tarafından hırsız olarak öldürülme riskiyle karşı karşıya kalırdı. Görünüşe göre hiç kimse bir yabanciya onun kim olduğunu veya ormanda ne yaptığını sormak için beklemezdi. Orta Çăğ'ın ilk yılları o kadar tehlikeli ve şiddetli zamanlardı ki, bir yabancıyı öldürmek, onu sakinleri soyabileceği, sığır çalabileceği veya çocukları kaçırabileceği bir köye sokmaktan daha iyi görünüyordu. Ayr1$\mathrm{ca}$, ulaşımın kusurları ve sorunları vardı. Su taşımacılığı her zaman korsanlar tarafından saldırıya uğrama veya gemi kazası geçirme olasılığına sahipti. At binmek de o kadar güvenli değildi. Biniciler attan dışarı atıldıklarında ağır şekilde yaralanabilirler ve hatta ölebilirlerdi. Bu tür şeyler genellikle beceriksiz sürücüler oldukları için değil, yolun kalitesi genellikle kötü olduğu için gerçekleşirdi. Yayalar da hırsızların saldırısına uğrama tehlikesiyle karşı karşıya kalırdı.

\section{Orta Çağ'ın Önemli Gezginleri}

Batılı Seyyahlar: Latin kaynakları, Orta Çağ seyahat yazarlarına ve harita yapımcilarına dünyanın farklı bölgelerini tanımlarken yararlanabilecekleri çeşitli seçenekler sundu. Her zaman birbiriyle uyuşmayan bu kaynak yelpazesi, Orta Çağ gezi literatürünün zaten çeşitli olan bir kültüre kolayca karıştığ 1 anlamına geliyordu. Yaşlı Pliny'nin eserlerinden yararlanan III. yüzyıla tarihlenen Julius Solinus gibi yazarlar, Asya ve Afrika'nın canavarlarla ve burunları bulunmayan, kendilerini gölgeleyebilecek kadar devasa ayakları olan ve kimi zaman köpek kafalarılya dikkat çeken garip insanlarla dolu çok sıcak yerler olduğu fikrini teşvik etmişti.

Orta Çăğa ait doğu anlatımlarından birisi olan ve Eski İngilizcede kaleme alınmış olan The Marvels of the East-The Wonders of the East (Doğunun Harikaları), çok çeşitli garip ve büyülü insanları ve hayvanları açıklar ve gösterir. Anlatılan harikalar, seyahat etmeyi engelleyen devasa ejderhalar, küllerinden doğan Anka kuşları ve dokunulduğunda insanların bedenlerini yakan tavuklardır. Doğunun Harikaları, dev karıncalardan nasıl altın çalınacağı gibi inanılmaz senaryolardan da bahseder. Fantastik ve barbar insanlardan da söz edilir. Örneğin yamyamlar Donestre ırkı, Homodubii yarı insan yarı eşek yaratıklar ve yelpaze gibi kulaklarıyla uyudukları ve örtündükleri panotti. Edward Said'e göre, bu kitapta anlatılar kültürel ve ırksal tipleme yoluyla yapılmaktadır. Bu açıdan, Orta Çağ Avrupalılarının farklı etnik kökenlerden insanlara bakışı genellikle merak, korku 
ve kurgu ile bağlantılıydı. Haliyle Orta Çağ'da Avrupa'nın Doğu'ya bakışında tuhaflıklar ve acayiplikler yerini muhafaza ediyordu.

Orta Çağ insanlarının bildiği Avrupa dışı topraklar arasında en önemlisi Hindistan'd1. Avrupal1lar, Hint Yarımadası hakkındaki bilgilerinin çoğunu, Eski Çă̆'ın klasikleşmiş Yunan kaynaklarından aldılar. Bu kaynaklara göre, yeryüzü cennetinin, dünyanın en doğu ucunda, Hindistan'da veya yakınında var olduğu düşünülüyordu. Bu meyanda Büyük İskender hakkındaki hikayeler Orta Çağ'da özellikle popülerdi. Makedonya Kralı Büyük İskender 4. yüzyılda Antik Yunan krallığının da lideri olarak, güç ve toprak arayışında Hindistan'a kadar seyahat etti. Aslında bu Doğu ile Batı'nın kültürel manada harmanlandığı bir Doğu Seferi'nden başka bir şey değildi. Birçok el yazması, İskender'in savaşlarını ve maceralarını muhteşem yaratıklarla süsleyerek anlatırlar. Doğu ile Batı kültürlerinin harmanlanması süreci Orta Çağ'da da bir dizi olayla devam etti. Bu olaylardan ilki 375'te Hunların başlattığ1 Kavimler Göçü'ydü. Bu göç Asya'dan Avrupa'ya; Avrupa'dan da Afrika'ya insanları göçe zorlamak yanında eski kıtalar arasında bilgi alışverişine de yol açmıştı. Orta Çağ'da Doğu-Batı karşılaşması İslam'ın gelişiyle bir kez daha sahneye konmuştu. Müslümanlar 711'de İspanya'ya geçecek, İtalya, Sicilya ve daha birkaç noktadan Avrupa'yla temas gerçekleşecekti. Elbette Müslümanların Avrupa'ya nüfuz etmesi bu karşılaşmada son nokta olmayacaktı. Avrupalıların İslam'a karşı tepkilerinin bir sonucu olan Haçlı Seferleri bu defa Batı'yı Doğu'ya getirecek ve uzun yıllar sürecek bir etkileşime başlangıç olacaktı. Adeta Hristiyanlık ile İslam'ın çatıştı̆̆ Çağ'da savaşlar kadar insanların hareketinde din de önemli bir rol oynadı. Hatta dinsel seyahatler ticari yolculukların önüne bile geçmişti.

Orta Çağ'da Hıristiyan gezginler Doğu'yu keşfetmeye yöneldi. Kudüs'e giderek Hz. İsa'nın ayak bastığı topraklarda bulunmayı gelenekselleştirdi. Böylece, gezginlik Avrupa'da kurumsallaşmaya başladı. Öyle ki Orta Çağ'da Avrupalı bir gezgin, mesleği ne olursa olsun, kutsal bir yeri ziyaret amacıyla yolculuk eden kişi sayıldr. Kudüs'ten hurma dalıyla dönen hacı, palmer sözcü̈̆̈̈̈ ile anıldı. Palmer sözcüğ̈̈ palmiye ağacının dalından türemiş bir isim olup hayatının bir bölümünü kutsal yerleri ziyaret ile geçiren dindar gezginlerin adıydı. Kudüs'e gezginci akını arttıkça daha sağlıklı seyahat için rehberler ve konukların ağırlandığı mekânların sayısı da her geçen gün çoğaldı.

Orta Ça ğ'ın ilk gezginlerinden birisi Hristiyan bir din adamıydı. Mısır'dan Hindistan'a yola çıkmıştı. Kendisi İmparator Justinianus döneminde Hindistan'a birkaç sefer yapan bir 6. yüzyıl gezginiydi. İskenderiyeli bir tacir olan Cosmas Indicopleustes (Hindistan'a yelken açan Cosmas ya da Keşiş Cosmas); Etiyopya ve Asya'nın bir kısmını dolaştıktan sonra, dönüşünde rahip olmuştur. Seyahatnamesi, "Dünyanın Hiristiyan Topografyası" başlığını taşımaktadır. Dört köşe olan dünyanın diğer yıldızlarla birlikte, uzunca büyük bir sandık içinde kapalı olduğunu kanıtlamak için yapılan kozmografik tartışmalar eserin başlangıcını teşkil etmekte ve bunu meleklerin fonksiyonları tartışmaları ve İbrani rahiplerinin kostümüne ait bir tarif izlemektedir. Cosmas, eserinde, Hindistan ve Seylan'daki hayvanların evrimi ve diğer bazı hayvanlar, biber fidanı ve Hindistan cevizi hakkında bilgi vermiştir. Hristiyan Topografyası adlı çalışma, en eski ve en ünlü dünya haritalarından bazılarını içeriyordu. Özellikle Hindistan ve Seylan tasviri tarihçiler için paha biçilmezdir. Cosmas, yaklaşık 550'de günümüzün kuzeyindeki Etiyopya'nın yanı sıra Eritre, Hindistan ve Seylan'1 ziyaret etmiş görünüyor.

Aslında, Hıristiyanlığın doğuşundan itibaren dindar Hristiyanlar, kutsal yerleri ziyaret konusunda büyük çaba harcamışlardır. Kutsal yerlere olan merak, zamanla daha da çoğalmış ve tarih, Hıristiyanlığın erken dönemlerinden başlayarak Filistin'e doğru yol alan kişileri kaydetmiştir. Bu hacılardan yedinci yüzyıl sonlarına doğru yaşamış Fransız Psikopos Arculf seyahatinin ayrıntılı bir raporunu kaleme almıştır (670). Arculf, Kudüs'ün topografik durumunu göstermekle işe başlamış ve kutsal şehrin etrafını çeviren suru tarif etmiştir. Bundan sonra, büyük, küçük bütün kiliseleri görmüş, İsa' nın çarmıha gerildiği tepe ile mezarını ziyaret etmiştir. Josapbat Vadisi, Zeytin Dağı, Ürdün, Lübnan, Lut Gölü, Nâsıra, Şam, Sur, İskenderiye ve İstanbul'u tarif etmiştir. 
Fransız piskoposundan kisa bir süre sonra $725^{\prime}$ te, bir İngiliz din adamı olan Willibald, dinsel amaçla aynı seyahati yapmış ve seyahatini aynı şartlarla tamamlamıştır. Willibald Southampton kontluğunda yaşamış zengin bir aileye mensuptur. Geçirdiği ağır bir hastalıktan sonra gençlik ça$\breve{g} 1$ Waltheim manastırında ibadetle geçirmiştir. Willibald, gençlik yıllarının sonuna gelince, Roma'daki Saint-Pierre kilisesinde ibadet etmeye karar vermiş ve onun çok kuvvetli israrları, babası Richard, kardeşi Wimebald ve genç kız kardeşi Walpurge'yi kendisine eşlik için karar vermeye zorlamıştır. 5 Şubat 722 tarihinde, Richard'ın yol yorgunluğundan güçsüz kalıp öldüğü bir sırada, iki erkek kardeşle kız kardeşleri, kış mevsimi sırasında Apeninler'i aştıktan sonra, Roma'ya girmişler, hepsi de şiddetli bir hastalığa tutularak, kış mevsiminin bir kısmını orada geçirmişlerdir. Willibald, sağlığı düzelir düzelmez kutsal yerlere kadar olan seyahat tasarısını sürdürmüştür. Erkek kardeşi ile kız kardeşini İngiltere'ye göndermiş ve birkaç din adamı ile yola çıkmıştır. Terracine ve Gaete yolu ile Sicilya'daki Catania ve Syracuse'ye doğru yelken açarak denize açılmışlar, Cos (İstanköy Adası) ve Samos'a (Sisam Adasi) uğradıktan sonra, İncil yazarı Yuhanna'nın, Marie-Madeleine'nin mezarları bulunan Efes şehrine çıkmışlardır. Midilli Adası'na geçmişler ve oradan da Kıbrıs'a hareket etmişler; Paphos ve Constance' 1 ziyaret etmişler ve havarilerden Saint-Thomas'ın mezarının bulunduğu Edissa adlı Finike şehrine varmışlardır. Willibald ve arkadaşları, bu yerde Müslüman Araplar tarafından casus olarak hapsedilmişler; fakat, kral, bir İspanyol'un tavsiyesi üzerine onları serbest bırakmıştır. Din adamları, şehri hemen terk etmişler ve o andan itibaren, yol programları hemen hemen piskopos Arculf'ün yoluna göre tertiplenmiştir. Suriye'de Şam'ı, Celile'de Nâsıra'yı, Turu Sina'yı, Tabariye Gölü'nü, Magdala'yı, Galgala'yı, Jéricho'yu ve Kudüs'ü ziyaret etmişlerdir. Kudüs, Josaphat vadisi, Zeytindağı, BeytLâhm, Hérode'un küçük çocukları öldürdüğü Thema, Laura vadisi ve Gazze bu dindar hac1ların gezdikleri yerler olmuştur. Willibald, Gazze şehrindeki Saint Mathias kilisesinde yapılan bir âyin sırasında, gözlerinin birdenbire görmez bir hale geldiğini ve görme duyusunu ancak iki ay sonra Kudüs'te Saint-Croix kilisesine girerken tekrar kazandığını anlatmaktadır. Willibald, bundan sonra, Kudüs'e 10 millik (yaklaşı 16 $\mathrm{km}$.) mesafedeki Diospolis vadisini, Akdeniz'e kıyı Sur ve Sayda'yı, bundan sonra da Lübnan, Şam, Şeyzer'i dolaşmış ve gezginler sonunda bütün kış mevsimini Kudüs'te geçirmişlerdir. Bu yorulmak bilmez dindar gezginler, yaptıkları keşif seyahatleriyle yetinmemişlerdir. Onlar, sırasıyla, Akkâ, Humus, Kudüs, Şam, Samariya, Sur'da bulunmuşlardır. Sur'da uzun bir zaman kaldıktan ve İstanbul'a hareket ederek burada da iki yıl kadar oturduktan sonra, Sicilya ve Kalabriya yolu ile Napoli ve Capoue'ya dönmüşlerdir. İngiliz din adamı, ülkesinden ayrıldıktan on yıl sonra İtalya'nın Cassino tepesindeki manastıra varmıştır. Bununla birlikte, onun için dinlenme zamanı henüz gelmemiştir. Papa Üçüncü Grégoire tarafından Franconie piskoposu olarak atanmış ve piskopos olduğu vakit kırk bir yaşında olduğu anlaşılmıştır. Piskoposluk makamını bir süre işgal ettikten sonra 745 yılında ölmüştür. Willibald, 938 yılında Papa Yedinci Léon tarafından aziz ilân edilmiştir.

MS. 9. yüzyıla gelindiğinde kâşifler Atlantik, Akdeniz, Kızıldeniz, Hint Okyanusu ve Çin Denizi'ni geçmiş; Norveç'ten Çin İmparatorluğu sınırlarına kadar olmak üzere sahillerin büyük bir kısmı görülmüş, ziyaret edilmiştir. Mısır'dan Etiyopya'ya, Anadolu'dan Kafkaslara, Hindistan ve Çin'den Tataristan'a kadar olmak üzere karaların iç kısımlarına cesaretle keşif seyahatleri de yapılmıştır. Gezginler tarafından tespit edilen çeşitli noktalar hakkında matematik bir açıklık henüz yoksa da hiç olmazsa, insanların ahlâk, gelenek ve görenekleri, çeşitli ülkelerin ürünleri, dinsel töreler yeteri kadar belirtilmiştir. Düzenli ve sürekli esen rüzgârlardan faydalanan gemiler, denizlerde daha güvenle seyir yapabilmişler; kervanlar, bir kıta içinde seyahat ederken nereye gitmekte olduklarını güvenle bilmişler ve bilim adamlarının yazılarıyla yayılmış bütün bu bilgiler topluluğu sayesinde, ticaret, Orta Çă̆'in son devresinde muazzam bir gelişme göstermiştir.

10. ve 11. yüzyılın başlangıcında Avrupa'nın kuzeyinde oldukça önemli bir coğrafî hareket meydana gelmiştir. Norveçliler Kuzey Denizi'nde 
dolaşmışlar ve az çok gerçek hikâyelerin bazılarına inanılacak olursa, Beyaz Deniz'e kadar uzanmışlar ve bugün Samoyedlerin bulunduğu bölgeleri ziyaret etmişlerdir. İrlanda'nın 861 y1lına doğru, İskandinav serüvencileri tarafından keşfedildiği ve Normanların bu ülkeyi kolonize etmekte gecikmedikleri ileri sürülmektedir. $\mathrm{Bu}$ devrede, Avrupa'nın en batısında bulunan yeni bir ülkeye sığınmış olan bir Norveçli (Kızıl Erik), arazinin görünüşüne hayran kalarak, bu ülkeye Yeşil Arazi ya da Grönland adını vermiştir. Fakat, Amerika kıtasının bu kısmı ile ulaştırma sağlanması çok zor olmuş ve Norveç'ten Grönland'a gitmek ve Grönland'dan Norveç'e dönmek için tam beş yıl geçirmiştir. Bununla birlikte, o kadar sert kışlar olmuştur ki, Kuzey Okyanusu tamamen donmuş ve Norveç'ten Grönland'a yaya veya kızakla gidilmesi imkânı doğmuştur. Fakat, hâlâ efsane ve söylentiler devrinde yaşadığımızı, çok yukarı kuzey bölgelerinin güzel gelenekler bakımından hayli zengin olduğunu unutmayalım. Bu Wikingliler Kanada açıklarına kadar da ulaşmışlardır.

Avrupalılara göre "hac tek bir bireyin yolculuğu, Haçlı Seferleri ise toplu hac yolculukları" sayılırdı. Haçlı Seferleri genel anlamda başarısız olunca Roma, kutsal yolculuklarda Kudüs'ün yerini ald. Papa VIII. Boniface, 1300 yılını "Bağışlama Yılı" ilan etti ve bu yılda Roma'yı ziyaret edenlerin günahlarının tümüyle bağışlanacağını duyurdu. Bu duyuru o günün koşullarında ulaşılması zor bir rakam olan 20.000 ziyaretçiyi Roma'ya çekmeyi başardı. Bu tip "Bağışlama Y1lı" etkinlikleri gelecekte de tekrarlanarak insanların Roma'yı ziyaret etmesi sürekli teşvik edildi.

Orta Çağ'da din uğruna seyahat edenler yalnız Hristiyanlarla sınırlı değildi. Navarra Krallığı şehri olan Tudela'da bir hahamın oğlu olan Benjamin de Tudela dünya üzerine dağılmış dindaşlarını görüp sayılarını bilmek amacıyla seyahat etmiştir. 1165 ila 1173 arasında, hemen hemen bütün bilinen dünyayı gezip görmüş ve seyahat hikâyesi, etkisi on altıncı yüzyıla kadar sürmüş olan çok detaylı ve hatta ince elenmiş bir belgeyi oluşturmuştur. Benjamin'in Barselona'dan başlayan seyahati Marsilya, Roma, Eflak, İstanbul, Akdeniz adaları, Filistin, Kudüs, Beyt-Lahm,
Şam, Baalbek, Ninova, Bağdat, Babil, Basra, İsfahan, Şiraz, Semerkant, Tibet, Malabar, Seylan, Kızıl Deniz, Misır, Sicilya, İtalya, Almanya ve Fransa'yı kapsamıştır.

Orta Çă̆'da Doğu mallarını satarak zengin olan Venedikli, Cenevizli ve Pizalı tüccarların hiçbiri bu toprakları aslında hiç görmemişlerdi. Bu tüccarların Uzakdoğu ile bağlantıları Doğu Akdeniz liman kentleri üzerinden sağlanıyordu. Değerli mallar İpek ve Baharat yolları üzerinden kendilerine ulaşabiliyordu. Müslümanlar çekinmeksizin Avrupalı tüccarlar ile İskenderiye, Halep ve Şam gibi merkezlerde ticaret yapar; ancak Müslüman Türkler, tüccarların bir adım daha ilerlemesine izin vermezdi. Bu Avrupalılar için Orta Çağ'ın demir perdesiydi. 1250-1350 yılları arasında bu demir perde, en azından İpek Yolu için, ortadan kalktı. Demir perdenin kalkmasına neden olan Moğollardı. Moğollar zamanında çok say1da misyoner diplomat, seyyah ve tüccar doğrudan Çin'e, İpek Yolu'nun başlangıcına gidebilme imkanına kavuştu. 1245 'te Fransisken keşiş Carpineli John (1185-1252) Papa tarafından Moğollara elçilikle görevlendirildi. Jean du Plan de Carpin, İtalya'nın Perouse bölgesinin bir kasabasında dünyaya gelen bir Fransisken'di. Carpini, yanında Bohemyalı Etienne olduğu halde, 6 Nisan 1245 tarihinde yola çıkmıştır. Kuman ülkelerini ve Türkistan'ı keşfetmiş; Tatarların gelenek ve görenekleri hakkında bilgiler vermiştir. Carpini, Papa adına yaptığı seyahati 1247 'de tamamlamış ve dönmüştür.

Carpini'nin Papa adına gerçekleştirdiği bir bakıma Moğolları yumuşatma ya da belki de Hristiyanlığa davet etme amaçları içeren bir çeşit resmi seyahat sonuç vermemiş ve Moğollar, eskiden nasıllarsa yine öyle sert ve haşin kalmışlardır. Bununla beraber, Fransisken papazının dönüşünden altı ay sonra, ismi Rubrucklu William (Guillaume de Rubruquis) olan Flaman (Belçika) kökenli başka bir rahip, Don ile Volga arasindaki bölgede yaşayan Tatarlara gönderilmiştir (1253-1255). Azak Denizi, Volga, Başkurtlar ülkesi, Karakurum, Astarhan, Derbent'i kapsayan diplomatik bir yolculuk gerçekleştirmiştir. O sıralarda, Fransa Kralı Saint Louis, Suriye Müslümanlarıyla savaşıyor ve bu savaş bütün şid- 
detiyle devam ederken, Moğol Prensi Erkaltay, Fransa Kralı lehine faydalı bir oyalama hareketi olmak üzere, İran tarafından saldırıda bulunuyordu. Bu prensin Hristiyanlığ 1 kabul ederek din değiştirdiği söylentileri ortalıkta dolaşıyordu. Olaydan emin olmak isteyen Saint Louis, papaz Rubruquis'e Erkaltay'ı kendi ülkesinde görüp durumunu incelemek görevini vermişti. Rubruquis ve arkadaşları, 1253 yılının Haziran'ında, İstanbul'a gitmek üzere gemiye binmişler, Tatarlar ülkesine ulaşan Fransa elçileri, Kuman topraklarına varmış; Don ile Volga arasındaki bölgeyi paylaşan Müslüman kabileler arasından geçerek, Başkurtlar ülkesini aşarak Carpini'nin, içine girmeden karşısında durduğu Karakurum'a ulaşmışlardır. Bununla birlikte, büyük hakan, Karakurum'daki başkentte o sırada bulunmuyordu. Rubruquis ile arkadaşları, bölgenin kuzey kısmında yükselen dağların öte tarafındaki saraya gitmek zorunda kalmışlardı. Rubruquis, birçok günlerini Mengü Han'ın sarayında geçirmişti. Rubruquis, büyük Han'ın kendisini birçok kereler huzura kabul edip görüşmesinden sonra, yola çıkma iznini almış ve Karakurum'a dönmüştü. Rubruquis, Karakurum'da bulunduğu sırada, Çinliler, töreleri, yazıları vesaire hakkında ilgi çekici dokümanlar toplamıştı. Sonra, Moğolların başkentini bırakarak, gelmiş olduğu yolu tekrar tutmuştu. Astarhan'a, Suriye'ye, Dağıstan bölgesinin Derbend şehrine, Nahcivan, Erzurum, Sivas, Kayseri, Konya'dan geçip Tarsus limanında ülkesine dönmek üzere gemiye binmişti. Ne var ki Carpini ve Rubruquis'un seyahatleri, Venedikli Marco Polo'nun ünü ve anlattıkları yanında gölgede kalmıştır.

John Mandeville, Marco Polo ve Pordenoneli Odoric Orta Çağ Avrupalılarına Doğu'ya özgü daha gerçekçi anlatılar bıraktılar. Orta Çağ seyyahları içerisinde Marco Polo, yazdıklarının çoğuna tanık olmasıyla diğerlerine göre daha öndedir. Orta Çağ Hristiyan gezginlerin en deneyimlisi, verimlisi ve etkilisi Marco Polo'ydu (12541324). Yolculuğu 24 sene sürmüştü. Çin'i bir uçtan bir uca okyanusa kadar katetti. Bu arada $\mathrm{Ku}$ bilay Han'ın danışmanlığını yaparak çeşitli kimliklere büründü. Dili rahatlıkla kullanabiliyordu. Böylelikle Çin kültürüne ve Çin'deki gündelik yaşama kolayca uyum sağladı. Kuşaklar boyunca
Polo'nun canlı ve gerçekçi Doğu yaşamı betimlemeleri Avrupa için Asya'nın keşfi niteliğinde olmuştu. Marco Polo, babası ve amcasının eşliğinde Kuzey İran üzerinden Tebriz, Karadeniz'in güneyindeki bir liman olan Trabzon ve sonra da İstanbul yoluyla tam 24 yıllık bir ayrılıktan sonra 1295 kışında Venedik'e dönebildi. Bir söylentiye göre, Venedikliden çok üç kılıksız Tatar'a benzeyen bu yabancıları soylu akrabaları kabul etmedi. Orta Çă̆ sonlarında Avrupa'dan Asya'ya karadan yapılacak güvenli bir yolculuğa ait en heyecan verici rehber elbette Marco Polo'nun seyahatnamesidir. Marco Polo, zengin, adil ve Hristiyanları bile hoş gören bir Çin imajı çizmiştir. Ne var ki keşfedilecek doğuya ilişkin en kapsamlı betimlemeler Mandeville'in seyahatnamesinde yer almıştır. 14. yüzyılda meçhul biri tarafından, Latince akademik çalışmalardan derlenmiş, daha sonra sürekli çevirisi yapılmış, uyarlanmıs, resimlenmiş ve yeniden basılmış olan Sir John Mandeville'in seyahat kitabı, dünyanın sınırları hakkında kapsamlı ve heyecan uyandırıcı bir panorama ortaya koymuştur. John Mandeville'in Seyahatleri, İngiltere' nin güneyindeki St Albans'tan 1332'de kutsal topraklara, Asya ve Afrika'ya bir yolculuğa çıkan bir şövalye olan John Mandeville'in hikayesini anlatmaktadır. Ne var ki böyle bir karakterin yaşayıp yaşamadığına dair herhangi bir delil bulunmamaktadır.

Mandeville, Hristiyan kaşiflerin yönünü yeryüzünün cenneti olarak nitelendirdiği Aziz John'un krallığına yönlendirmiştir. Mandeville uzak diyarları, zengin ve tuhaf krallıkları; buradaki halkların ilginç gelenekleri, kurumları, alfabeleri ve yiyecekleri ile doldurmuştur. Böylelikle, dolaylı ama yanlışsız olarak, Yunanlılarla başlayan egzotik Doğu anlatılarının devamını yazmıştır. John Mandeville'in 14. yüzyıldaki heyecan dolu yolculukları Marco Polo'nun 1290'lardaki Doğu anlatımından çok daha etkili olmuştur. Defalarca çoğaltılmış, kısaltılmış, resimlenmiş, elyazması şeklinde tercüme edilmiş ve matbaa çağında bile popülaritesini yitirmemiştir. Mandeville'in hikayesinde Hristiyan mucizeci rahipler, Plinius'un canavar ırkları, yamyamlar, Amazonlar, tek gözlü adamlar, Wemmy'ler, köpek kafalılar, ayaklarını kızgın güneşe karşı şemsiye gibi kullanabilen 
tek ayaklı adamlar bir arada yer almıştır. Mandeville Avrupa'dan uzaklaştıkça daha da inanılmaz hikayeler anlatmıştır. Mandeville'i Avrupa'da etkili kılan bir yönü de dünyanın etrafında gemiyle dolaşılabileceği kuramının yaygınlaşmasına neden olmasidır. Bu konuda bazısı bilimsel, bazısı masalsı anlatımlarda bulunmuştur.

13. yüzyılın sonlarından başlayarak, Fransisken rahipleri Doğu Asya'da bir varlık oluşturmak için kararlı bir çaba başlatmışlardı. Pekin'in ilk Katolik Piskoposu olan Montecorvinolu John ve Çin ve Hindistan'ı dolaşan Giovanni de Marignolli gibi misyonerler bu konuda ilk öncülerdi. Ancak bu din adamları içerisinde en çok öne çıkan kişi, 1316 civarında Doğu'ya doğru yola çıkan Çek kökenli bir Fransisken olan Pordenoneli Odoric'ti. Odoric, İran'da bir süre kaldıktan sonra, Java, Sumatra ve Borneo'ya gitmişti. Çin'e vardığında, başlangıçta Pekin'de kaldı ancak sonraki üç yıl boyunca geniş çapta seyahat etmeye devam etti, özellikle Hangzhou'dan etkilendi. Daha sonra Tibet üzerinden eve dönmeye karar verdi. Seyahat anlatıları Avrupa'da son derece etkili oldu.

Hristiyanların Moğolların açtı̆̆ 1 yoldan Çin'e doğru yol aldıkları bir dönemde Cenevizliler Cebelitarık Boğazı'nın ötesinde bir yol bulabilmenin arayışına girişmişlerdi. 1291'de Cenevizli Vivaldi kardeşler kötü sonuçlanan, Afrika'yı denizden dolaşma projeleri için, Cenova'dan yola çıkmışlardı.

Macaristan Kralı Bela, 1235'te dört Dominiken keşişi ananevi dinlerini yaşayan akrabalarını bulmak için Volga taraflarına gönderdi. Bunlardan sadece Julian adlı bir keşiş yolculuğu tamamlayıp geri dönebildi. Julian ve çağdaşı Macarlar, Magna Hungaria "Büyük Macaristan" olarak anılan bir bölgede Doğu Macarlarının yaşadığına inanıyordu. Julian, seyahatine başladığı tarihlerde, Moğollar Bulgar Hanlığı sınırlarına geldiler. O da geri döndü. Yazdığı kronik Moğolların Bulgar ülkesindeki faaliyetlerini içermesi ile Katolik Hristiyanları Moğol tehdidi konusunda uyarması bakımından tarihi açıdan da önemli ve kıymetli bilgiler içermektedir.

Sınırlı sayıda olsa da Moğollar zamanında bazı Avrupalı tacirler İpek Yolu'ndan Doğu Asya'ya ilerledi. Floransalı bir banker ailesi tarafından
1340 'ta gönderilen Francesco Balducci Pegolotti, kısa adıyla Bardi, gezgin tacirler için hazırladığı el kitabında gelişen ticaretle ilgili bazı ipuçları verdi. Bu kitap, kara yolculuğu yapanların gereksinimi olan kentler arasındaki mesafeler, yerel tehlikeler, ağırlık ölçüleri, fiyatlar ve kurlar, gelenek-görenekler, gümrük kuralları üzerinde pratik denebilecek tavsiyelerin yanı sıra ne yemeline yememeli, nerelerde konaklamalı gibi bilgiler de içermekteydi.

Moğol Asrı da denen 13. yüzyılda bazı Avrupalılar Doğu'ya, bazı Çinliler de Batı'ya yöneldiler. Evlerine dönen Batılılar ve yolculuk eden Çinliler, yanlarında oyun kağıtları, porselen, tekstil, sanatsal içerikli desenler, çeşitli mobilya stilleri getirirken Avrupalı üst sınıf halkın da yaşamlarının yeni bir şekil kazanmasına sebep olmuşlardı. Kâğıt para, matbaa, barut gibi çok önemli yenilikler dünyayı sarstı. Bu yenilikler önce Ortadoğu'ya, sonra da Araplar ve diğer uluslar aracılı̆̆ıyla Avrupa'ya taşındı. Aslında böylesine anlık kavramlar çok nadir olarak benimsenirdi.

Moğolların ardından Timur, kendi topraklarında Batılıların güvenlik ve rahat içinde İran'dan Tebriz'e kadar ulaşmasını sağladı. Timur'un gücü Semerkant'ta sona eriyordu. Semerkant Timur zamanına gelindiğinde Asya'daki Atina gibiydi. Ne var ki Timur 1405 'te öldügünde Semerkant hayalet bir şehre döndü. Çin'e ve yakınına kadar gidilen yollar artık Avrupalılar için kapanmıştı. Çinliler ülkelerine Avrupalıların girmesine de izin vermiyordu. Çinliler kendilerini dış dünyaya karşı izole etme yöntemine başvuruyorlardı. Madridli soylu Ruy Gonzales de Clavijo ve iki arkadaşı Kastilya Kralı II. Henry tarafından Timur'a yollanmıştı. Amaç Türklere karşı Timur'la bir ittifak kurmaktı. Clavijo ve beraberindekiler gemilerle Trabzon'a gelip, oradan karayoluyla Semerkant'a ulaştılar. Ancak onlar Semerkant'a vardıklarında Timur ölmüş ve varisleri arasında çoktan taht kavgası başlamıştı.

Son olarak doğudan ayrıntılı bilgi getirebilen Avrupalı ne bir misyoner ne bir serüvenci ne bir diplomat ne de tüccardi. Bu kişi Hans Shiltberger adındaki, Bavyeralı iyi bir aileye mensup isteksiz bir yolcuydu. Niğbolu Savaşı'nda (1396) Macar Kralı Sigismund tarafından yönetilen Haçlılarla 
birlikte Türklere esir düştüğü sırada on beş yaşındaydi. Sonraki otuz iki sene boyunca Shiltberger, Osmanlı Sultanı Yıldırım Bayezid'in kölesi olmuştu. Daha sonra da Timur ve onun mirasçılarının kölesi oldu. Kahyalık ve benzeri birçok iş yaptı. Özgürlügüne kavuşuncaya değin tek amacı hayatta kalmayı başarabilmekti. Savaşlar nedeniyle bir yandan bir yana savrulurken bir köle gözüyle Türkler ve Tatarların yaşantılarını gözleme şansı yakaladı. Clavijo gibi o da Semerkant'tan ötesini göremedi. Amazon savaşçıları ve Kahire hakkında önemli bilgiler verdi.

\section{Doğulu Seyyahlar}

Çinli Seyyahlar: Batı'nın dikkatini Doğu'ya çevirdiği bir zaman diliminde Doğu'dan, özellikle de Çin'den Batı'ya doğru giden az sayıda gezgin vardır. Bunlardan birisi de Çinli Nasturi bir keşiştir. Doğu'nun Marco Polo'su olarak adlandırılan Rabban Bar Sauma, Uygur asıllı Nasturi bir Hristiyan keşişti. Kudüs'e gidip hacı olmaya karar verdi ve Asya karasını boydan boya katetti. Sonunda Bağdat'a ulaştı, ancak kutsal topraklardaki bir savaş Kudüs'e seyahatini engelledi. Bir Ermeni manastırında birkaç yıl geçirdikten sonra, İran'ın Moğol hükümdarı Rabban'1 diplomatik bir görevle Avrupa'ya yollamak istedi. Korkusuz keşiş İstanbul'dan geçti ve Roma'ya vardı. Bazı kardinallerin onun bir sapkın olduğundan şüphelendiği Roma'dan zorlukla canını kurtarıp ayrıldı. Fransa Kralı Philip'in yanında kaldı ve Bordeaux yakınlarında Atlantik Okyanusu'na ulaştı ve burada İngiltere Kralı Edward ile tanıştı. Başarıyla İran'a döndükten sonra Rabban, Azerbaycan'da bir manastır kurmak üzere emekliye ayrıldı. Modern tarihçilere Orta Çağ Avrupası hakkında büyüleyici bir yabancı bakış açısı sağlayarak seyahatlerinin bir günlüğünü dikkatle tuttu. $L i$ Da ve Chen Cheng (1365-1457), 1410'larda Orta Asya'da tehlikeli bir sefer yapan iki Çinli hadımdı. Li Da, Asya'nın kalbine iki kez seyahat etmiş açık ara daha deneyimli bir gezgindi. Ama gezip gördüklerini yazmadı, bu yüzden neredeyse unutuldu. Ancak Chen Cheng ayrıntılı bir günlük tuttu. 1396'da Chen, sınır savunması kurmak için batı bölgesine diplomatik bir görevle gönderildi. 1397'de İmparator Yongle tarafından Vietnam'a elçi olarak yollandı. 1414, 1416 ve 1420'de Chen Cheng, Semerkant'taki Timurlu hanedanının sarayına yollanan bir Ming heyetine önderlik etti. Heyetin seyahati Herat'a kadar sürdü. Heyetin içerisinde Li Da da vardı.

Çinlilerin 15. yüzyılda başlattığı deniz seferleri Chen Cheng ve Li Da gibi Çin diplomatlarının seyahatlerine oranla daha görkemli ve etkileyici oldu. Çin'in deniz seferleri bir hadım ve amiral olan Cheng Ho (Zheng He) (1371-1433) kumandasında gerçekleștirilmişti. Ho, Yunnan'daki bir Müslüman aileden geliyordu. Babası hacı olmak için Mekke'ye gitmişti; bu nedenle Güneydoğu Asya ve Hint Okyanusu'ndaki ticaret ve hac yolları hakkında yeterince bilgi sahibiydi. 14051433 arasında yükünün yanı sıra yaklaşık 500 kişilik taşıma kapasitesine sahip, açık deniz yolculuğu yapabilen her biri 1500 tonluk 60'ın üzerinde muazzam çunke'den (gemi) oluşan filoyla yedi yolculuk yapmıştı. Yaklaşık 100 yıl sonra Hint Okyanusu'na ulaşabilen Avrupa gemilerinin ağırlığ $\mathrm{du}$ ve bu tarihte tüm Çin donanması yaklaşık 6500 gemiden oluşuyordu. 1405-1411'deki ilk üç seyahat Cava, Tayland ve Sri Lanka'yla, Hindistan sahilindeki Kalikut ve Koçin'e yapıldı. 1415'te Sumatra'ya ve daha sonra Hint Okyanusu'nu geçerek Hürmüz'e, Körfez ile Maldiv Adaları'na uğramadan doğruca Aden'e gitti. Son üç seyahat Doğu Afrika'ya, özellikle Mogadişu, Mozambik ve Madagaskar Boğazı'na yapılmıştı. Bu yolculuklardan birinde iki zürafa, geri dönen konvoydan önce Malindi'den Çin'e gönderildi. Bu seyahatler Avrupalıların 16. yüzyılın başlarında yaptıklarından çok farklıydı. Çinlilerin, karşılaştıkları halkları fethetme veya dinlerini zorla değiştirtme girişimleri olmadı; zorla din değiştirtme düşüncesi, bir sürü dini deneyimlemiş olan Çinliler için bilinmeyen bir kavramdı. Çinliler, filonun 1409 'da uğradığ $\breve{1}_{1}$ Sri Lanka'daki olayların gösterdiği üzere, ziyaret edecekleri insanlar hakkında son derece detaylı bilgi sahibiydiler. Olayın anısına dikilen bir kitabe -Çince, Tamilce ve Farsça olmak üzere- üç dilde yazılmıştı. Adadaki her üç din için de imparatordan hediyeler getirilmişti. Çin'e geri dönüldüğünde, seyahatlerin sonuçları çoğunlukla yayımlandı. En ünlü üç kitap Batı Okyanuslarının Barbar Krallıkları Üze- 
rine Risale (1434), Galaksi Yolundaki Teknenin Keşfettiği Harikulade Şeyler (1436) ve Okyanusların Harikaları'ydı (1451).

Müslüman Seyyahlar: Hz. Muhammed ve Dört Halife dönemlerinden itibaren İslâm fetihlerini kolaylaştırma, yeni fethedilen İslâm beldelerini ve halkını tanıma, başta hadis olmak üzere çeşitli ilimleri tahsil etme vb. amaçlarla Müslümanlar tarafından seyahatler gerçekleştirilmiştir. İslam dininin tebliğ edilmesi de yapılan seyahatlerin önemli amaçlarından birisi olmuştur. Seyahatler bazen bir devletin elçisi olarak da yapılabilmiştir. Birûnî'nin Tahkiku mâi'l-Hind adlı eserinde olduğu gibi Müslüman seyyahlar yaptıkları seyahatlerinde başka inançları araştırmak, çeşitli düşüncelerle tanışmak ve farklı toplumları tanımak gibi amaçlar da gütmüşlerdir. Müslümanların kısa bir zamanda Atlas okyanusundan Ceyhun Nehri'ne kadarki geniş bir alana tek başlarına hâkim olmaları ve bu alanda seyahat özgürlügünü ve güvenliğini sağlamaları, büyük bir toplumsal ve kültürel hareketliliğe yol açmıştır.

Bilinen ilk İslam seyyahı Mekhûl b. Ebû Müslim'dir (ö. 112/730). Mısır, Suriye ve Irak şehirleriyle bütün Ortadoğu'yu ve Hicaz bölgesini dolaşmıştır. Dokuzuncu yüzyılda bir tacir olan Basralı Süleyman (Süleyman et-Tacir) Basra Körfezi'nden hareket edip Asya'yı izleyerek Çin kıyılarında karaya çıkmıştır. Bu seyahatin hikâyesi, birbirinden farklı iki kısmı içermektedir: Bu kısımlardan birincisi, bu seyahatin gerçek sahibi Süleyman tarafından 851 yılında yazılmıştır. Diğeri ise, birinci kısmı tamamlamak amaciyla Ebu Zeyd Hasan adındaki bir coğrafyacı tarafından 878 yılında yazılmıştır. Bu seyahatname, bir taraftan, dokuzuncu yüzyılda, Basra Körfezi sahil ülkelerinin M1sir ve Arabistan sahilleriyle, diğer taraftan Hindistan ve Çin'in geniş eyaletleriyle cereyan etmiş ticari ilişkileri gün ışığına çıkarmıştır. Süleyman Umman Denizi, Sumatra, Seylan, Siyam Körfezi, Çin Denizi'ni dolaşmıştır.

Abbâsî Halifesi Muktedir-Billâh, 921'de İdil Bulgar Hükümdarı Almuş (Almış) Han'ın İdil'deki karargâhına İbn Fadlân'ın başkanlığında dinî bir heyet göndermiştir. İbn Fadlân, bu seyahatle ilgili kitabında (Risâletü İbn Fadlân) Bağdat'tan ayrılıp yine oraya dönünceye kadar gördükleri- ni, Bulgar ülkesini ve Rusya'yı, ayrıca buralarda yaşayan halkı ve âdetlerini anlatmıştır. İbn-i Fadlan'ın seyahatnamesi Rus tarihi hakkında en eski bilgileri veren kaynak olması bakımından da değerlidir. Eb̂̂ Bekir İbnül-Arabî̀den (ö. 1148) itibaren seyahatnâmeler günlük anılar şeklinde de yazılmıştır. İbn Cübeyr bu yeni türü daha ileriye götürmüş, eserinde yüksek bir edebî üslûp kullanmış olması dolayısıyla seyahat edebiyatının onunla başladığı söylenmiştir. İbn Cübeyr hac maksadıyla çıktığı seyahatine 1183 'te Girnata'dan başlamış ve yolculuğu iki yıl üç buçuk ay sürmüştür. Seyahatnâmesi Rihletü İbn Cübeyr veya Rihletü'l-Kinânî olarak tanınır. Seyahati esnasında Misır, Hicaz, Irak ve Suriye'ye de uğrayan İbn Cübeyr izlenimlerini günlük notlar halinde kaleme almış, ekonomik, sosyal ve siyasal değerlendirmelerde bulunmuştur.

Müslümanları seyahate yönelten önemli faktörlerden birisi de hac oldu. İslam'ın beş şartından birisi maddi gücü yeterli ve yokluğunda ailesini geçindirebilecek her Müslüman'ı, yaşamı boyunca en azından bir defa Mekke'yi ziyaret etmeye yönlendirdi. Hac sırasında hacılar iki parçadan oluşan ihram adı verilen beyaz giysilerini giyerler. Bu onların Allah karşısında eşit olduklarını gösterir. Hac ibadeti boyunca tıraş olmaz ve tırnaklarını kesmezler. Kâbe'nin çevresinde yedi kez dönmek ve Mekke yöresinde bazı yerlerden geçmek zorundadırlar. Döndüklerinde de hacı olarak anılmaya hak kazanmış olurlar. İbn-i Batuta (1304-1374) Orta Çağ'ın en meşhur Müslüman gezginidir. Henüz 21 yaşındayken Fas'taki Tanca kentinden ayrıldığında niyeti hacca gitmekti. Gezilerini anlattı̆̆ seyahatnamesi onu Müslümanların Marco Polo'su yapmıştı. Kendine seyahatlerinde bir kural belirlemişti: "Aynı yoldan asla iki kez geçmeyecekti." Ne var ki Mekke'ye dört kez hac amacıyla gitti ve bu kuralı çiğnedi. Toplam yetmiş beş bin kilometre yol katetti. Bu yönüyle kendinden önceki bütün gezginlerin rekorunu kırmayı başardı. Bütün Müslüman ülkeleri ve bu ülkelerin komşularını ziyaret etti. Delhi, Maldivler ve Seylan gibi yerlerde kadılık bile yaptı. Yolculukları bilinmeyeni keşfetmek gibi bir amaca hizmet etmedi. Yine de onun seyahati korsanlara ve güçlü sultanlara rağmen bir Müslüman'ın dünyayı tanımak için dolaşabileceğini ortaya 
koydu. Müslümanlar için hac gezilerinin önemi hiçbir zaman bitmedi. İbn-i Batuta hac olayını Müslüman dünyasının yıllık kurultayı olarak tanımladı. Dünyanın önemli gezginlerinden sayılan İbn Battûta seyahatnâmelere yeni bir anlayış ve üslûp getirmiş, ülke ve beldelerin özelliklerinden çok insanların ve halkların durumları, sosyal hayat, inanç ve gelenekleriyle ilgili bilgiler vermiş, bundan dolayı seyahatnâmesi tarih, coğrafya ve edebiyat yönünden olduğu kadar etnografik, antropolojik, sosyokültürel açllardan da büyük bir değer taşımıştır. Seyahatleri 1325 'ten itibaren otuz yıla yakın sürmüş olan İbn Battûta'nın gezdiği yerler arasında Türkiye, Hindistan, Çin, Endülüs, Batı Sudan, Cezayir, Tunus, Libya, Mısır gibi ülkeler bulunmaktadır. Gezileri esnasında tuttuğu notlar, Hindistan'da soyguna uğraması ve Kalküta Limanı'nda binmiş olduğu geminin batmasıyla zarar görmüş ve eserin yazılması bazı konularda sadece gezginin hâfızasına dayand1rılmıştır. Türk-Moğol tarihiyle ilgili önemli bilgiler ihtiva eden seyahatnâmesi Tufetü'n-nüzzâr fî garâibil-emsâr ve 'acâibi'l-esfâr adını taşır. Rihle adıyla da zikredilir.

Gerçek bir seyahate dayanan ilk Farsça eser, Nasır-ı Hüsrev'in Sefer-nâme'sidir. Aynı zamanda ilk dönem Müslüman seyyahlarından sayılan Nâsır-1 Hüsrev, Aralık 1045'te, hacca gitmek üzere yola çıkmış ve yaklaşık yedi yıl sürecek seyahatine başlamıştır. Nîşâbur, Damgan, Simnân, Kazvin ve Şemîrân'a uğrayarak Tebriz'e ulaşmış; oradan Hoy, Ahlat, Bitlis, Silvan ve Diyarbakır yoluyla Urfa'ya kadar gitmiştir. Suriye ve Filistin şehirlerini ziyaret ettikten sonra ilk haccını gerçekleştirmiştir. Ardından İran'ın tamamını, Anadolu, Suriye, Filistin, Hicaz, Misır, Sudan ve Tunus'u ziyaret etmiştir. Türk edebiyatında ilk seyâhatnâme örneği Hoca Glyaseddin Nakkaş' in Acâibü'l-Letâif'idir. Hitay Sefaretnamesi adıyla da anılmaktadır. 1422'de tamamlanan eserde Hoca Giyaseddin, Timur'un oğlu Mirza Şahruh'un Çin imparatoruna gönderdiği elçilik heyetinin Herat'tan başlayan ve üç yıl devam eden yolculuğunu anlatmaktadır.

Orta Çă̆ Seyyahlarmnn ve Orta Çă̆ Zihin Dünyasının Geleceğge Aktardığı Kültürel Miras: İşin aslı, Orta Çağ biterken ve insan oğlu 15. yüzyıla gi- rerken seyyahların, keşişlerin ve tacirlerin kıta dışından getirdikleri haberler Avrupa'da önemli yer tutmaktaydı. Bu haberler çoğunlukla inançlarının ve intikam duygularının yönlendirmesiyle maceraya atılmış bir dizi seyyahın gördükleri ve işittikleri tuhaflıkları da içerisinde barındırmaktaydı. Seyyah raporları, Çin ile Hindistan'ı dünyaya sevk ettikleri ticari mallarla anmaktaydı. Çok daha az sayıda Çinli seyyah Batı'ya yönelik serüvenlere atılmıştı. Çinliler ve Hintliler ile Avrupalılar arasında bir bilgi uçurumu olduğu açıktı.

Yeni Çăğ'ın ilk sanclarının başladığı zaman diliminde bile gerçeklerle mitler ve fanteziler büyük ölçüde karışmaktaydı. Avrupa'da, hâlen, kayıp adalar, Asya ya da Afrika'da Müslümanların yaşadığı bölgelerden ötede bir yerde yaşayan Hristiyan Kral Aziz John ve Batı'da Atlantis kıtasından söz eden ve bilimsel temellere dayanmayan inanışlar da halk nazarında önemli yer meşgul ediyordu. Her şeye rağmen, birçok ulus ve dile ayrılmış olsa da, Avrupa günümüzde de olduğu gibi tutarlı bir bütündü. Baskın bir biçimde ay$\mathrm{n} 1$ 1rktan gelen insanları barındırmaktaydı. Buna karşılık Afrika ve çok daha belirgin olmak üzere seyyahların gözdesi Asya, olağanüstü bir çeşitlilik göstermekteydi. Orta Çağ'da Batı'nın Doğu'ya olan merakının altında biraz da bu çeşitliliğin etkisinin olduğunu unutmamak gerekir. Seyyahlar, birçok itici faktörün yanında "acaib ve garaib" in peşinden koşan insanlardır.

Akdeniz Avrupalılar için tanıdıktı ve denizin öte yakasında yaşayanlarla Avrupalılar her zaman temas halinde olmuştu. Bir yandan bu deniz Hristiyanlıkla İslam'ın kesiştiği bir arenaydı. İslamiyet ve Hristiyanlık Orta Çağ'ın küsmüş ikiz kardeşleriydi ve aynı kaynaktan gelmekteydi. Doğum yerleri ortaktı ve Ortadoğu'ydu. Hac gibi bir ibadet bu iki dinin temsilcilerini Ortadoğu'da karşı karşıya getirmekteydi. Hristiyan hacıların ana hac merkezi Kudüs'ken Müslümanların ana hac merkezi Hicaz'dı. Daha da önemlisi her iki dinden seyyahların önemli bir kısmının yola ç1kış hikayesi hac ibadetine dayanmaktaydı. Orta Çağ'ın bilinen dünyasında Asya'nın güney ve doğu, Afrika'nın orta ve güney kesimlerindeki ırkların bütün acayip ve garipliklerine rağmen, 
Akdeniz' in her iki yakasında yaşayanlar ortak bir mirası paylaşanlardı.

Batı Hristiyan dünyası, özellikle de Hristiyan seyyahlar İranlıların, Hintlilerin ve Çinlilerin daha uzakta kalan topraklarından ayırmak üzere süreç içerisinde bugün üzerinde yaşadığımız Türkiye topraklarını "Küçük Asya" olarak adlandırdılar. Bu nedenledir ki seyyah anılarında Anadolu adı Küçük Asya kaldı. Benzer biçimde, Uzak Doğu, Batı'nın ilgisini çekmeye başlayınca yaşadı̆̆ımız toprakların adı, biraz da önyargılı bir biçimde, Yakın Doğu veya Orta Doğu'ya dönüştü.

Karşılıklı seyyahların gidip geldiği bir zaman diliminde Müslümanlar dünyayı biri coğrafi öbürü aynı anda dini ve siyasi olmak üzere iki yoldan tanımlamaktaydı. Arapça, Farsça, Türkçe ve öteki İslam dillerinde yazılmış coğrafya eserleri dünyayı ayırmada çoğunlukla "iklim"leri temel aldı. Müslümanların "iklim"leri bütünüyle coğrafi niteliktedir ve herhangi bir biçimde dini, kültürel, etnik ya da siyasal çağrışımlar taşımamaktadır. Müslümanlara göre, dünyada önemli ve etkili olan ikinci bir ayrım çizgisi İslamiyet'in hüküm sürdügü topraklar ile henüz bu safa katılmamış olan yerlerdi.

Hristiyanlık ve İslamiyet'in kimlikleri belirlediği bir çağda Hristiyanlar düşmanlarını Müslüman kimliği yerine Mağribi, Serazen, Türk ya da Tatar; Müslümanlar da Avrupa'nın sakinlerini Hristiyan yerine Rum, Frenk ya da Slav olarak etnik ve bölgesel özelliklere göre adlandırdı. Dinsel nitelendirme söz konusu olduğunda ve savaş baltaları toprağın altından çıkarıldı ğında niteleme her iki taraf için de aynıydı: Kâfir ya da Gavur. İki din üzerinde temellenen Orta Çağ yolculukları ve seyahat anlatıları yukarıda bahsedilen farklılıklar ve ortaklıkların açığa çıkmasında önemli bir belirleyici oldu ve günümüzdeki bazı düşmanlıkların ve tanımlamaların da alt yapısını oluşturdu.

Bu arada günümüz yazarları ve filmleri için de Orta Çă̆ bir esin kaynağı olmayı sürdürüyor. Orta Çağ'da seyahati anlamak için Ivanhoe, Joan of Arc, The Radicals, El Cid, Sant Antonio di Padova, Monty Python ve Holy Grail filmlere bak1labilir. Her ne kadar bu filmler birer kurgu olsa da o tarihlerin seyahat koşulları ve zorluklarını anlamaya yardımcı olmaktadırlar.

Gelecek sayıda Keşifler çağında kaşifler ve seyahatleriyle ilgili yazımızda görüşmek üzere.

\section{SEÇILMIŞ KAYNAKÇA}

Akpınar, A. (1998). Kur'an Aydınlığında Seyahat. Ankara: Türkiye Diyanet Vakfı Yayınları.

Boorstin, D. J. (1994). Keşifler ve Buluşlar. (Çev. Fatoş Dilber). İstanbul: İş Bankası Yayınları.

Cait Stevenson. What Was It Like To Travel During the Middle Ages? Part 1: Going by Road. https://www.medievalists.net/2019/08/travel-middle-ages-road/, Erişim tarihi: 19 Ekim 2021.

Chaucer, G. (2005). The Canterbury Tales. (Editör: Jill Mann). Londra: Penguin Books.

Grafton, A. (2004). Yeni Dünyalar Eski Metinler: Geleneğin Gücü ve Keşiflerin Yarattığı Şaşkınlık. (Çev. Füsun Savc1). İstanbul: Kitap Yayınevi.

Grant, N. (2001). Everyday Life in Medieval Europe. Florance: McRae Books.

Labarge, M. W. (1983). Medieval Travellers. New York ve Londra: W. W. Norton \& Company.

Livingstone, J. (2018). Travel, Trade and Exploration in the Middle Ages. https://www.bl.uk/medieval-literature/articles/travel-trade-and-exploration-in-the-middle-ages, Erişim Tarihi: 1 Kasim 2021.

Newman, P. B. (2011). Travel and Trade in the Middle Ages. Jefferson, NC: McFarland \& Company.

Olher, N. (1989). The Medieval Traveller. (transl. Caroline Hillier). Woodbridge, Suffolk: The Boydell Press.

Said, E. (1978). Orientalism. ${ }^{1}$ New York: Pantheon Books.

Touati, H. (2016). Ortaçă̆'da İslam ve Seyahat: Bir Âlim Ŭ̆raşının Tarihi ve Antropolojisi. (Çev. Ali Berktay). 2. Bask1. İstanbul: Yapı Kredi Yayınları.

Türkiye Diyanet Vakfı İslam Ansiklopedisi. Muhtelif Ciltler

Ülgen, P. ve Çaylı, M. (2020). Eski Bir Şövalyenin Gözünden XIV. Yüzyılda Ege Adaları: Bizans İmparatorluğu, Haçlilar ve Türkler. Cappadocia Journal of History and Social Sciences, 14: 93-102.

Verne, J. (1982). Dünyanın Keşfi-I. (Çev. Ferid Namık Hansoy). İstanbul: İnkılap ve Aka Kitabevleri.

Wikipedia.

Yazıcı, H.-Coşun, M.-Dilek, K. (2009). Seyahatname. TDVİA. Cilt- 37. (ss. 9-16). İstanbul: Türkiye Diyanet Vakfı Yayını.

Doç. Dr. Murat HANILÇE, Tokat Gaziosmanpaşa Üniversitesi

Fen Edebiyat Fakültesi, Tokat.

E-posta:murathanilce@gop.edu.tr 
Turizm Tarihi İncelemeleri

Tablo 2. Orta Çă̆ Seyyahları ve Seyahat Ettikleri Ülkeler/Yerler

\begin{tabular}{|c|c|c|c|c|}
\hline Seyyah Adt & Kökeni & Eseri & Tarih & $\begin{array}{l}\text { Gördüğ̈̈/Anlattığı } \\
\text { Yerler }\end{array}$ \\
\hline $\begin{array}{l}\text { Egeria (Etheria ya da } \\
\text { Aetheria) }\end{array}$ & Galyalı-Ispanyol & $\begin{array}{l}\text { Peregrinatio ya } \quad \text { da } \\
\text { Itinerarium Egeriae }\end{array}$ & $380^{\prime}$ ler & $\begin{array}{l}\text { Hristiyanların Kutsal } \\
\text { topraklarına bir kadının } \\
\text { yolculuğunu içeren } \\
\text { Latince seyahatname }\end{array}$ \\
\hline $\begin{array}{l}\text { Cosmas Indicopleustes } \\
\text { (Keșiş Cosmas) }\end{array}$ & $\begin{array}{l}\text { İskenderiyeli Yunan } \\
\text { tüccar }\end{array}$ & $\begin{array}{l}\text { Christian Topography } \\
\text { Hristiyan Topografyası }\end{array}$ & 6. yüzyıl & $\begin{array}{l}\text { Hindistan, Seylan, } \\
\text { Etyopya, Eritre vd. }\end{array}$ \\
\hline $\begin{array}{l}\text { Arculf } \\
\text { (irlandait } \\
\text { Adomnan'in } \\
\text { anlatımila/625-704) }\end{array}$ & $\begin{array}{l}\text { Orta Doğu'ya giden } \\
\text { en eski Bat। Avrupalı, } \\
\text { Alman }\end{array}$ & $\begin{array}{l}\text { De Locis Sanctis (Kutsal } \\
\text { yerler Hakkında) }{ }^{1} \\
\text { İrlandalı Aziz Adomnan } \\
\text { kaleme alındı. }\end{array}$ & 670 & $\begin{array}{l}\text { Kutsal yerler hakkında } \\
\text { rehber kitap }\end{array}$ \\
\hline $\begin{array}{l}\text { Mekhul bin Ebu Müslim } \\
\text { (öl. 730) }\end{array}$ & 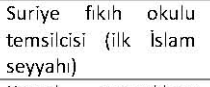 & $?$ & 8. yüzy॥l & $\begin{array}{l}\text { Misır, Suriye, Irak, Hicaz, } \\
\text { Ortadoğu }\end{array}$ \\
\hline $\begin{array}{l}\text { Aziz Willibald } \\
\text { (700-787) } \\
\text { (Heidenheimli } \\
\text { Huneberc'in anlatımila) }\end{array}$ & $\begin{array}{ll}\text { Kutsal topraklara } \\
\text { seyahat eden ilk } \\
\text { Ingiliz }\end{array}$ & $\begin{array}{l}\text { The Hodoeporican }{ }^{2} \text { of St. } \\
\text { Willibald, } \\
\text { (Aziz Willibald'ın Seyahat } \\
\text { Rehberi) }\end{array}$ & 8. yüzyıl & $\begin{array}{l}\text { Kutsal yerlere yolculuk } \\
\text { (Kudüs ve çevresi) }\end{array}$ \\
\hline $\begin{array}{l}\text { Yahyô b. Hakem el-Bekrî } \\
\text { (El-Gazal) } \\
\text { (9. Yüzyil) }\end{array}$ & $\begin{array}{l}\text { Endülüs } \\
\text { Halifesi Emevi } \\
\text { Abdurrahman } \\
\text { tarafından } 208 \text { (824) } \\
\text { ylında Normanlara } \\
\text { gönderilen elçi }\end{array}$ & $?$ & 9. Yüzyıl & Norveç vs. \\
\hline $\begin{array}{l}\text { Sellâm et-Tercümân } \\
\text { (9. Yüzyil) }\end{array}$ & $\begin{array}{l}\text { Abbâsî Halifesi Vâsik- } \\
\text { Billalh'ın 228'de (842) } \\
\text { Çin Seddi hakkında } \\
\text { bilgi r edinmek } \\
\text { amacıyla gönderdiği } \\
\text { elçi }\end{array}$ & ? & 9. Yüzyıl & Semerra'dan Çin'e \\
\hline Süleyman et-Tâcir & $\begin{array}{l}\text { Müslüman Arap } \\
\text { Seyyah (Çin ve Hint } \\
\text { Okyanusu hakkında } \\
\text { ilk Arapça eser veren } \\
\text { kişij) }\end{array}$ & Ahbârü'ș-Sîn ve'|-Hind & 851-852 & $\begin{array}{l}\text { Çin Hindistan ve } \\
\text { Malezya }\end{array}$ \\
\hline $\begin{array}{l}\text { Aziz Ansgar (Anskar- } \\
\text { Anschar-Oscar) } \\
\text { (801-865) }\end{array}$ & $\begin{array}{lr}\text { Doğu } & \text { Frank } \\
\text { Krallığ'nın kuzey } & \text { kun } \\
\text { kesiminde Hamburg- } \\
\text { Bremen } \\
\text { Başpiskoposu }\end{array}$ & $\begin{array}{l}\text { Vita Ansgarii } \\
\text { The Apostle of the North }\end{array}$ & 9. уüzуıl & $\begin{array}{l}\text { Kuzey Avrupa } \\
\text { (İsveç ve dolaylarında } \\
\text { misyonerlik faaliyetleri) }\end{array}$ \\
\hline $\begin{array}{l}\text { El-Cahiz (Ebu Osman Amr } \\
\text { bin Bahr el-Kinani el- } \\
\text { Fukaimi el-Basri) (767- } \\
\text { 869) }\end{array}$ & $\begin{array}{l}\text { Basra doğumlu Afro- } \\
\text { Arap }\end{array}$ & $\begin{array}{l}\text { Hayanlar Kitabı } \\
\text { Türklerin Faziletleri } \\
\text { Cimriler Kitabı } \\
\text { Hilafet Ordusunun } \\
\text { Menkıbeleri ve Türklerin } \\
\text { Faziletleri } \\
\text { Kitâbü't-Tebașsur bi't- } \\
\text { ticâre } \\
\text { Kitâbü'l-Büldân. Kitâbü'l- } \\
\text { Emșâr ve 'acâ'ibü'l-büldân } \\
\text { vd. }\end{array}$ & 9. yüzyıl & $\begin{array}{l}\text { Mekke, Medine, Kûfe, } \\
\text { Şam, Antakya, Mısır vd. }\end{array}$ \\
\hline Tấciribn Vehb el-Kureșî & $?$ & $?$ & 870 & $\begin{array}{l}\text { Sîrâf Limanı'ndan } \\
\text { yapț̆ı̆ı Çin ve Hindistan } \\
\text { seyahati }\end{array}$ \\
\hline $\begin{array}{l}\text { Bernard Monachus (Hacı } \\
\text { Bernard-Bilge Bernard- } \\
\text { Keșiș Bernard) } \\
\text { (9. Yüzyll) }\end{array}$ & Frank piskoposu & $\begin{array}{l}\text { Malmesbury'li William, } 12 . \\
\text { yüzylın başlarındaki Gesta } \\
\text { Regum Anglorum (İngiltere } \\
\text { Krallarının Tarihi) adlı } \\
\text { çalış̧asında Bernard'a } \\
\text { atıfta bulundu. Mabilion, } \\
1672 \text { 'de Paris'te yayınlanan } \\
\text { Acta Sanctorum Ordinis } \\
\text { Benedicti'sinde onun } \\
\text { seyahat programını } \\
\text { yayınladı. }\end{array}$ & $865-871$ & $\begin{array}{l}\text { Akdeniz, Italya, Misir, } \\
\text { Kutsal topraklar (Kudüs } \\
\text { ve çevresi) ve Fransa }\end{array}$ \\
\hline $\begin{array}{l}\text { Ibn Hurdâzbih (Ebü'- } \\
\text { Kasım Ubeydullah b. } \\
\text { Abdillâh b. Hurdâzbih) } \\
\text { (öl. 913?) }\end{array}$ & $\begin{array}{l}\text { İslam coğrafyacısı } \\
\text { (Islam } \\
\text { coğrafyacılarının } \\
\text { babası) }\end{array}$ & $\begin{array}{l}\text { Kitâbü'|-Mesâlik ve'l- } \\
\text { memâlik }\end{array}$ & 9. yüzy॥l & Irak, Hindistan, Çin vs. \\
\hline
\end{tabular}

${ }^{1}$ Bede'nin Ecclesiastical History of the English People (İngiliz Halkının Din Tarihi) kitabının 5. cildinin 15-17 bölümlerinde Adamnan'ın Locis Sanctis'i özetlenmistir.

${ }^{2}$ Latince Hodoeporicon kelimesi seyahat rehberi anlamına gelmektedir ve sekizinci yüzyılda Kutsal Topraklara yapılan bir hac yolculuğunun günümüze ulaşan tek anlatısıdır ve Adaman/Arculfun (670) eseriyle benzer bir tarz ve içeriğe sahiptir.

${ }^{3}$ Vita Anskarii'den, Misyoner Arkadaşı Piskopos Rimbert tarafindan çevrilmiştir. 
Turizm Tarihi İncelemeleri

Tablo 2. Orta Çağ Seyyahları ve Seyahat Ettikleri Ülkeler/Yerler (Devam)

\begin{tabular}{|c|c|c|c|c|}
\hline $\begin{array}{l}\text { Ibn Rüste (Ebû Ali Ahmed } \\
\text { b. Ömer b. Rüste) } \\
\text { (öl. 913?) }\end{array}$ & $\begin{array}{l}\text { Isfahan|ı coğrafyacı ve } \\
\text { astronom }\end{array}$ & el-A'lâku'n-nefise & 9. yüzyıl & $\begin{array}{l}\text { Bağdat üzerinden hacca } \\
\text { gidiş vd. }\end{array}$ \\
\hline $\begin{array}{l}\text { Et-Taberî (Ebû Cafer } \\
\text { Muhammed b. Cerîr b. } \\
\text { Yezîd el-Âmüî̀ et-Taberî } \\
\text { el-Bağdôdî) } \\
\text { (öl. 923) }\end{array}$ & $\begin{array}{l}\text { İslam müfessiri, } \\
\text { tarihçi, muhaddis ve } \\
\text { fakih }\end{array}$ & Târîhü'l-ümem ve'l-mülûk & 9. yüzy॥l & Arap yarımadası vs. \\
\hline $\begin{array}{l}\text { Ibn A'Sem El-Kûfi (Ebû } \\
\text { Muhammed Ahmed b. } \\
\text { A'sem ei-Küfi et-Ahbâri) } \\
\text { (öl. 932) }\end{array}$ & $\begin{array}{l}\text { Şii tarihçi, şair ve din } \\
\text { adamı }\end{array}$ & Kitabü'|-Fütuh & $900^{\prime}$ ler & $\begin{array}{l}\text { Hazar torakları, Harezm, } \\
\text { Horasan, Anadolu vs. }\end{array}$ \\
\hline $\begin{array}{l}\text { Ya'kub et-Turtûșî (9-10. } \\
\text { Yüzyıl) }\end{array}$ & $\begin{array}{l}\text { İspanya'da bir Yahudi, } \\
902 \text { yllinda Kurtuba } \\
\text { \{Córdoba) halifesinin } \\
\text { elçisi olarak Alman } \\
\text { Imparatoru Otto'yu } \\
\text { ziyaret }\end{array}$ & ? & 902 & Alman ve Slav toprakları \\
\hline $\begin{array}{l}\text { Ibnü'-Fakih el-Hamedanî } \\
\text { (869-942) }\end{array}$ & $\begin{array}{l}\text { Fars tarihçi ve } \\
\text { coğrafyacı }\end{array}$ & Muhtasar Kitabü'|-Buldan & 10. уӥzyıl & $\begin{array}{l}\text { Arap yarımadası, Mısır, } \\
\text { Mağrib, Suriye, Filistin, } \\
\text { Anadolu, Irak, Iran, } \\
\text { Azerbaycan, } \\
\text { Mâverâünnehir, } \\
\text { Türkistan ve Yedisu }\end{array}$ \\
\hline $\begin{array}{l}\text { El-Mes'ûdî (Ebü't-Hasen } \\
\text { All b. el-Hüseyn b. Alî et- } \\
\text { Mes'ûdi el-Hüzelî) } \\
\text { (öl. 956) }\end{array}$ & $\begin{array}{l}\text { Arap tarih ve } \\
\text { coğrafya âlimi, } \\
\text { seyyah }\end{array}$ & $\begin{array}{l}\text { Mürûcü'z-zeheb } \\
\text { et-Tenbîh ve'|-işrâf }\end{array}$ & 10. уӥzy॥l & $\begin{array}{lr}\text { İspanya } & \text { dişında } \\
\text { zamanının } & \text { İslam } \\
\text { Dünyası, Hindistan vd. }\end{array}$ \\
\hline $\begin{array}{l}\text { Ibn Fadlan } \\
(877-960)\end{array}$ & $\begin{array}{l}\text { Arap din bilgini ve } \\
\text { gezgini, Abbasi } \\
\text { diplomat। }\end{array}$ & $\begin{array}{l}\text { Risâletü Ibn Faḍlân fi } \\
\text { Vașfír-rihhle } \\
\text { Ibn Fadlan Seyahatnamesi }\end{array}$ & 10. yüzyıl & $\begin{array}{l}\text { Rey, Nîşâbur, Merv, } \\
\text { Buhara, Volga boyları }\end{array}$ \\
\hline $\begin{array}{l}\text { Olga } \\
\text { (öl. } 969)\end{array}$ & Rus (Kiev) Prensesi & $\begin{array}{ll}\text { Olga's Visit } & \text { to } \\
\text { Constantinople } & \end{array}$ & 10. уӥzуыl & İstanbul \\
\hline $\begin{array}{l}\text { Kremonah } \quad \text { Liutprando } \\
(922-972)\end{array}$ & $\begin{array}{l}\text { Lombardiyal| tarihçi } \\
\text { ve din adamı }\end{array}$ & $\begin{array}{l}\text { Repot on Mission to } \\
\text { Constantinople } \\
\text { (Bizans Notarı) }\end{array}$ & $963-968$ & İstanbul \\
\hline $\begin{array}{l}\text { Ebû Dülef el-Yenbuî } \\
\text { (Mis'ar bin Mühelhil) (öl. } \\
\text { 1000) }\end{array}$ & $\begin{array}{l}\text { Arap seyyah ve şair, } \\
\text { Samanî saray şairi ve } \\
\text { kâtibi, diplomat }\end{array}$ & 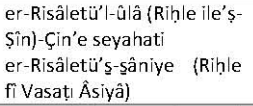 & 941-943 & $\begin{array}{l}\text { Çin, Bakü, Tiflis, Erdebil, } \\
\text { Tûs, Nîsâbur, Hûzistan } \\
\text { ve İsfahan, Tanca vd. }\end{array}$ \\
\hline $\begin{array}{l}\text { Kizul Erick } \\
(950-1003)\end{array}$ & Norveçli kâşif & $\begin{array}{l}\text { Saga of the Eric the Red } \\
\text { (KIzıl Erik'in Sagası) }\end{array}$ & $950-1003$ & Grönland \\
\hline $\begin{array}{l}\text { Leif Erickson } \\
(970-1020)\end{array}$ & Kız|| Erick'inn oğ|u & K|zı| Erick'in Sagası'ndan & 1000 & $\begin{array}{l}\text { Kuzey Amerika kıyları- } \\
\text { Kanada açıkları-Winland }\end{array}$ \\
\hline $\begin{array}{l}\text { Haraid Hardrade, }(111 . \\
\text { Haraid) } \\
\text { (1015-1066) }\end{array}$ & Norveç Kralı & $\begin{array}{l}\text { Saga of } \quad \text { Harald } \\
\text { Hardrade,(Harald } \\
\text { Hardrade'in Sagasi) }\end{array}$ & $1015-1066$ & İstanbul, vs. \\
\hline $\begin{array}{l}\text { Nasir-1 Hüsrev } \\
\text { (1004-1073) }\end{array}$ & $\begin{array}{l}\text { Belhli, Gazneli ve } \\
\text { Selçuku saraylarında } \\
\text { görev de alan İsmaili } \\
\text { şairi, filozof ve seyvah }\end{array}$ & Sefername & 1045-1052 & $\begin{array}{l}\text { Nişabur, Tebriz, Hoy, } \\
\text { Anlat, Bitlis, Silvan, } \\
\text { Diyarbakır, Harran, } \\
\text { Suriye, Filistin, Kutsal } \\
\text { Topraklar (Hac), Hac } \\
\text { dönüš̈ Kahire, Irak ve } \\
\text { İran üzerinden Belh }\end{array}$ \\
\hline $\begin{array}{l}\text { Afrikal Konstantin } \\
\text { (Constantinus Africanus) } \\
\text { (1010?-1087) }\end{array}$ & $\begin{array}{lr}\text { Tunuslu } & \text { bir } \\
\text { Müslüman } & \text { iken } \\
\text { sonradan Hristiyan } \\
\text { olmuş İslam } \\
\text { Avrupab'ya } & \text { tanının } \\
\text { mütercim } & \end{array}$ & $\begin{array}{l}\text { The History and } \\
\text { Description of Africa and of } \\
\text { the Notable Things Therein } \\
\text { Contained } \\
\text { Description of Timbuktu } \\
\text { The History and } \\
\text { Description of Africa: } \\
\text { Borno }\end{array}$ & 11. yüzyıl & $\begin{array}{l}\text { Mısır, } \quad \text { Bağdat, } \\
\text { Hindistan, Habeşistan, } \\
\text { Afrika kıtası }\end{array}$ \\
\hline $\begin{array}{l}\text { Ebû Ubeyd El-Bekrî (öl. } \\
\text { 1094) }\end{array}$ & Endülüslü coğrafyacı & $\begin{array}{l}\text { El-Mesalik ve'|-Memalik } \\
\text { el-Mugrib fi Zikri Bilâdi } \\
\text { Ifríkıyye ve'l-Magrib }\end{array}$ & 11. уüzyıl & Afrika ve Gana \\
\hline $\begin{array}{l}\text { Daniel (Seyyah Daniel- } \\
\text { Hacr Daniel-Kievli Daniel) } \\
\text { (1106-1107) }\end{array}$ & Rus başrahip & $\begin{array}{l}\text { Kutsal Topraklarda Rus } \\
\text { Başrahip Daniel'in Hac } \\
\text { Yolculuğu } \\
\text { Sir C.W.Wislon tarafindan } \\
\text { açiklamalı (Londra, 1895) }\end{array}$ & 12. уӥzуıl & 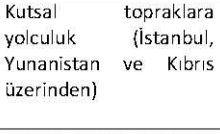 \\
\hline $\begin{array}{l}\text { Foucher de Chartres } \\
\text { (1059-1128) }\end{array}$ & $\begin{array}{l}\text { Fransız rahip, I. Haçl। } \\
\text { seferinde bulundu. }\end{array}$ & $\begin{array}{l}\text { The Chronicle of Fulcher of } \\
\text { Chartres }\end{array}$ & $1096 \mathrm{vd}$. & $\begin{array}{lr}\text { Birinci Haçlı Seferine } \\
\text { katıldı. } & \text { Anadolu } \\
\text { üzerinden } & \text { Maraş'a } \\
\text { geçti. Kutsal topraklarda } \\
\text { hizmet etti. }\end{array}$ \\
\hline
\end{tabular}


Turizm Tarihi İncelemeleri

Tablo 2. Orta Çă̆ Seyyahları ve Seyahat Ettikleri Ülkeler/Yerler (Devam)

\begin{tabular}{|c|c|c|c|c|}
\hline $\begin{array}{l}\text { Yehuda Halevi } \\
(1075-1141)\end{array}$ & $\begin{array}{llr}\text { Tudelalı ya da } \\
\text { Toledolu (Ispanya) } \\
\text { Sefarad Yahudisi } \\
\text { hekim, şair ve filozof }\end{array}$ & El-Kitabü'l-Hazeri (Kuzari) & 12. yüzy॥l & Hazarlar \\
\hline $\begin{array}{l}\text { Ebû Bekir ibnü't-Arabî } \\
(1076-1148)\end{array}$ & $\begin{array}{lr}\text { Endülüslü } & \text { Mâlikî } \\
\text { fakihlerinin } & \text { önde } \\
\text { gelenlerinden, } \\
\text { muhaddis }\end{array}$ & er-Rihle (Tertîbü'r-rịhle) & 12. yüzyıl & $\begin{array}{l}\text { Suriye, Irak, Hicaz ve } \\
\text { Misir }\end{array}$ \\
\hline $\begin{array}{l}\text { Eudes de Deuil (Odon de } \\
\text { Deuil) } \\
\text { (1110-1162) }\end{array}$ & $\begin{array}{l}\text { Fransız tarihçi, din } \\
\text { adamı, Ikinci Haçl। } \\
\text { Seferinde bulundu. }\end{array}$ & $\begin{array}{l}\text { De Profectione Ludovici VII } \\
\text { in Orientem } \\
\text { (VII. Louis'in Doğu'ya } \\
\text { Yolculuğu Üzerine) }\end{array}$ & $1147-1149$ & $\begin{array}{l}\text { İkinci Haçlı Seferinde VII. } \\
\text { Louis'in yolculuk yaptığı } \\
\text { güzergâh (Fransa'dan } \\
\text { Antakya'ya) }\end{array}$ \\
\hline $\begin{array}{l}\text { Idrisî̀ (Ebû Abdillâh } \\
\text { Muhammed } \quad b . \\
\text { Muhammed b. Abdillâh b. } \\
\text { idrîs eş-Serif es-Sebtî es- } \\
\text { Sikulli) } \\
\text { (öl. 1165) }\end{array}$ & $\begin{array}{lr}\text { İslam coğrafyacısı, } \\
\text { botanikçisi, } & \text { seyyahı } \\
\text { (Septe'de } & \text { doğdu. } \\
\text { Palermo'da } & \text { öldü. } \\
\text { Sicilya } & \text { Norman } \\
\text { krallarına } & \text { hizmet } \\
\text { etti.) } & \\
\end{array}$ & $\begin{array}{l}\text { Nüzhetü'l-müştâk } \\
\text { fi'htírâkıı'l-âfâk } \\
\text { (Kitâbu Rucâr (Roger) ve el- } \\
\text { Kitâbü'r-Rucârî) }\end{array}$ & 1154 & $\begin{array}{l}\text { Dünya coğrafyası, yedi } \\
\text { iklim vd. }\end{array}$ \\
\hline $\begin{array}{l}\text { Tudelah Benjamin } \\
\text { (1130-1173) }\end{array}$ & $\begin{array}{l}\text { Tudelalı (İspanya), } \\
\text { Sefarad } \\
\text { gezgin }\end{array}$ & $\begin{array}{l}\text { The Itinerary of Benjamin } \\
\text { of Tudela }\end{array}$ & $1165-1173$ & $\begin{array}{l}\text { Roma, Yunanistan, } \\
\text { İstanbul, Kıbris, Filistin } \\
\text { vd. }\end{array}$ \\
\hline $\begin{array}{l}\text { ibn Munkiz (Usame ibn } \\
\text { Munkiz) } \\
\text { (1095-1188) }\end{array}$ & $\begin{array}{l}\text { Munkizoğulları } \\
\text { hanedanına mensup } \\
\text { bir emîr, tarihçi ve } \\
\text { önemli bir edip } \\
\text { (Surive'de doğdu) } \\
\text { Zengi ve Fatımi } \\
\text { hizmetinde bulundu. } \\
\text { Haçlı Seferlerine şahit } \\
\text { oldu. }\end{array}$ & $\begin{array}{l}\text { el-Menâzil ve'd-diyâr } \\
\text { Abbârü'l-büldân }\end{array}$ & 12. yüzyıl & $\begin{array}{l}\text { Hasankeyf, Bitlis, Ahlat, } \\
\text { Musul, Bağdat, Kudüs, } \\
\text { Mısır vd. }\end{array}$ \\
\hline $\begin{array}{l}\text { ibn Cübeyr } \\
(1145-1217)\end{array}$ & $\begin{array}{l}\text { Endülüslü } \quad \text { Arap } \\
\text { seyyahı. }\end{array}$ & $\begin{array}{l}\text { Rihletü İbn Cübeyr veya } \\
\text { Rihletü'|-Kinânî }\end{array}$ & 1183 & $\begin{array}{l}\text { Gırnata (Granada)'dan } \\
\text { hac maksadıyla Arap } \\
\text { Yarımadası, Misır, Hicaz, } \\
\text { Irak ve Surye }\end{array}$ \\
\hline $\begin{array}{l}\text { Robert de Clari } \\
(1170-1216)\end{array}$ & Fransız şövalye & İstanbul'un Zapt। (1204) & $1203-1204$ & $\begin{array}{ll}\text { İstanbul (Dördüncü } \\
\text { Haçl| Seferi) }\end{array}$ \\
\hline $\begin{array}{l}\text { Regensburglu Petachiah- } \\
\text { Ratisbonlu Petachiah }\end{array}$ & Alman haham & $\begin{array}{l}\text { Travels of Rabbi Petachia of } \\
\text { Ratisbon }\end{array}$ & $1170-1187$ & $\begin{array}{l}\text { Doğu Avrupa, Kafkaslar, } \\
\text { Orta Asya, Polonya, } \\
\text { Rusya, Suriye, Anadolu, } \\
\text { İran, Ermenistan ve } \\
\text { Yunanistan }\end{array}$ \\
\hline 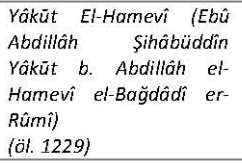 & $\begin{array}{l}\text { Rum asıllı Müslüman } \\
\text { coğrafyacı, tarihçi, } \\
\text { edip ve seyyah }\end{array}$ & $\begin{array}{l}\text { Mu'cemü'l-büldân } \\
\text { Mu'cemü'l-üdebâa }\end{array}$ & 13. yüzyıl & $\begin{array}{lr}\text { Bizanslılar, } & \text { Türkler, } \\
\text { Hazarlar, } & \text { Bulgarlar, } \\
\text { Saklebîler, } & \text { Ruslar, } \\
\text { Zencler, } & \text { Çinliler, } \\
\text { Haçlılar, Moğollar, } & \\
\text { çeşitli yer adları vd. }\end{array}$ \\
\hline $\begin{array}{l}\text { Novgorodlu Anthony } \\
\text { (Antoine) } \\
\text { (öl. 1232) }\end{array}$ & Rus aşoiskopos & $\begin{array}{l}\text { Description des Lieux- } \\
\text { Saints de } \\
\text { Constantinople par } \\
\text { Antoine, Archevêque de } \\
\text { Novgorod }\end{array}$ & 1200 & İstanbul (Hac yolculuğu) \\
\hline Rahip Julian & Macar & $\begin{array}{l}\text { On the Tracks of Friar Julian } \\
\text { Journeys across Mongolia }\end{array}$ & 1235,1237 & $\begin{array}{l}\text { Volga dolaylar।-Moğol } \\
\text { toprakları }\end{array}$ \\
\hline $\begin{array}{l}\text { Giovanni da Plan del } \\
\text { Carpine } \\
\text { (1185-1252) }\end{array}$ & $\begin{array}{l}\text { İtalyan diplomat, } \\
\text { başpiskopos ve gezgin }\end{array}$ & $\begin{array}{l}\text { The Journey of Friar John of } \\
\text { Plano de Carpini (1245- } \\
\text { 1247)-Moğolistan } \\
\text { Seyahatnamesi 13. Yüzyllda } \\
\text { Avrupa'dan Asya'ya } \\
\text { Yolculuk (1245-1247) }\end{array}$ & $1245-1247$ & $\begin{array}{l}\text { Kuzey, Orta Asya ve } \\
\text { Moğol toprakları }\end{array}$ \\
\hline $\begin{array}{l}\text { William Rubruck (Kessis } \\
\text { Rubrucklu William- } \\
\text { Guilloume de Rubrouck) } \\
\text { (1220-1293) }\end{array}$ & $\begin{array}{lr}\text { Flaman } & \text { asılll! } \\
\text { Fransisken } & \text { misyoner } \\
\text { ve seyyah }\end{array}$ & $\begin{array}{l}\text { The Journey of Friar } \\
\text { William of Rubruck (1253- } \\
\text { 1255)-Moğolların Büyük } \\
\text { Hanına Seyahat }\end{array}$ & $1253-1255$ & $\begin{array}{l}\text { Orta Doğu, Orta Asya } \\
\text { (Moğol toprakları) }\end{array}$ \\
\hline $\begin{array}{l}\text { Kazvini (Zekeriyyôa b. } \\
\text { Muhammed) (öl. 1283) }\end{array}$ & $\begin{array}{l}\text { İslam coğrafyacısı } \\
\text { (Müslümanların } \\
\text { Pilinius'u) }\end{array}$ & $\begin{array}{l}\text { Âsârü̈l-bilâd ve ahbaarü̈'|- } \\
\text { 'ibâd } \\
\text { Acaibu'l-Mahlukat ve } \\
\text { Garaibu'l-Mevcûdat, } \\
\text { (Tuhaf Yaratıklar ve Acayip } \\
\text { Varlıklar) }\end{array}$ & & $\begin{array}{l}\text { Yeryüzü şekilleri, iklim } \\
\text { çeşitleri, milletler ve } \\
\text { ülkeler, Anadolu'nun } \\
\text { birçok şehir ve kasabası } \\
\text { ile Orta Asya Türk } \\
\text { boyları }\end{array}$ \\
\hline Vivaldi Kardeşler & $\begin{array}{l}\text { Cenevizli denizci } \\
\text { kardeşler }\end{array}$ & - & 1291 & $\begin{array}{lr}\text { Afrika'yl } & \text { denizden } \\
\text { dolanma } & \text { projesi } \\
\text { (başarısız bir girişim) }\end{array}$ \\
\hline $\begin{array}{l}\text { Marco Polo } \\
\text { (1254-1324) }\end{array}$ & $\begin{array}{l}\text { Bat dünyasına Asya } \\
\text { ve Uzak Doğu'yu }\end{array}$ & $\begin{array}{l}\text { Il Millione } \\
\text { Travels of Marco Polo } \\
\text { (Kendisiyle } \\
\text { birlikte }\end{array}$ & $1271-1295$ & Venedik'ten Çin'e \\
\hline
\end{tabular}


Tablo 2. Orta Çă̆ Seyyahları ve Seyahat Ettikleri Ülkeler/Yerler (Devam)

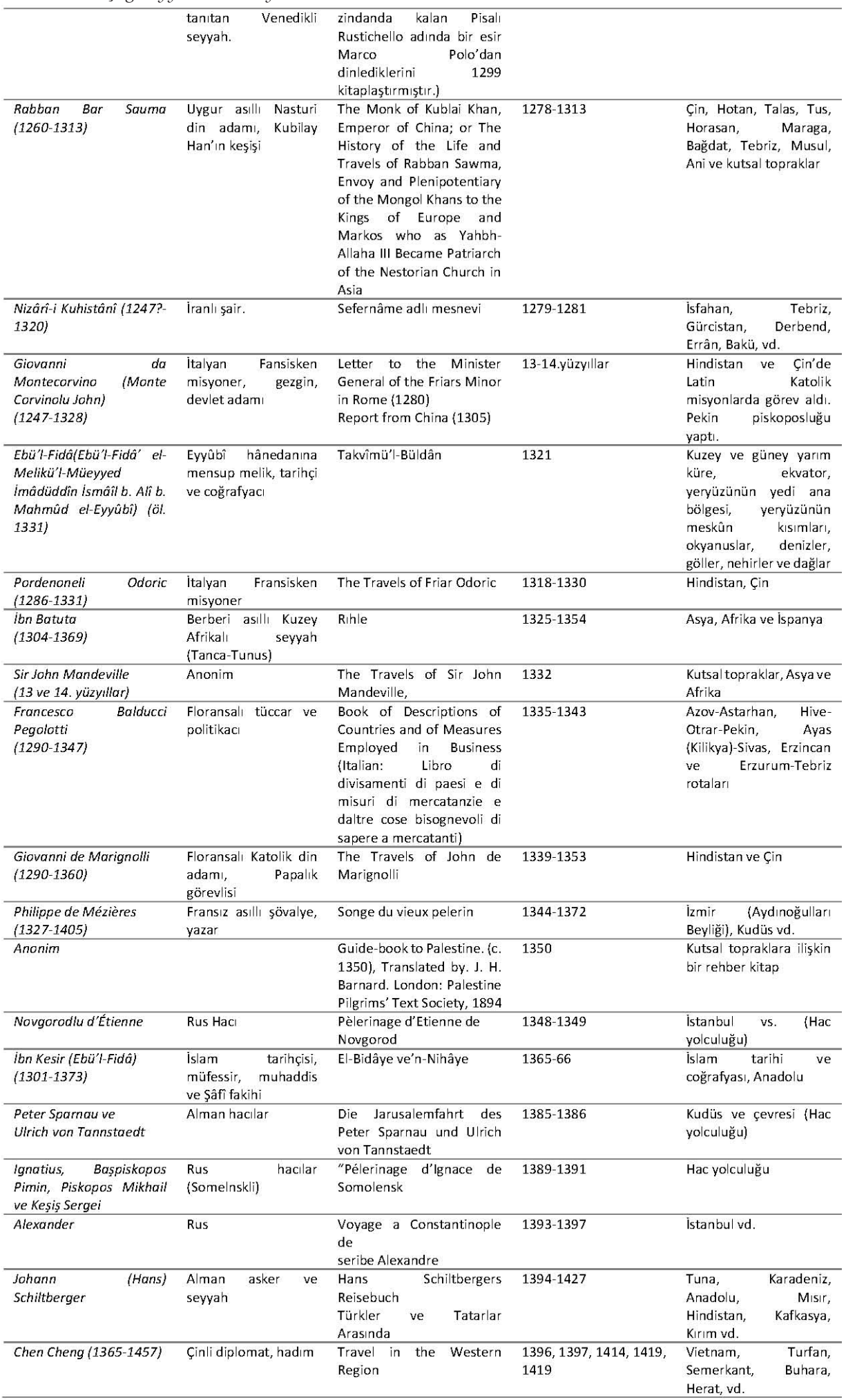


Turizm Tarihi İncelemeleri

Tablo 2. Orta Çağ Seyyahları ve Seyahat Ettikleri Ülkeler/Yerler (Devam)

\begin{tabular}{|c|c|c|c|c|}
\hline & & $\begin{array}{l}\text { A Record of the Barbarian } \\
\text { Countries in the Western } \\
\text { Region." }\end{array}$ & & \\
\hline $\begin{array}{llll}\text { Marshal Jean } & 11 & \text { Le } \\
\text { Maingre (Jean } & \text { II } & \text { Le } \\
\text { Meingre) } & & & \\
(1366-1421) & & \end{array}$ & $\begin{array}{l}\text { Fransız Şövalye ve } \\
\text { Komutan }\end{array}$ & $\begin{array}{l}\text { Le Livre des faits du bon } \\
\text { messire Jehan le Maingre, } \\
\text { dit Boucicaut. maréschal de } \\
\text { France et gouverneur de } \\
\text { Jennes }\end{array}$ & $1396-1399$ & $\begin{array}{l}\text { Niğbolu Savaş'nda } \\
\text { bulundu }\end{array}$ \\
\hline Guillebert de Lannoy & $\begin{array}{l}\text { Flemenk seyyah ve } \\
\text { diplomat }\end{array}$ & $\begin{array}{l}\text { Voyages et Ambassades } \\
1399-1450\end{array}$ & $1399-1450$ & Baltkk, vd.. \\
\hline Grethenios & Rus hacı & $\begin{array}{l}\text { Pèlerinage } \\
\text { l'archimandrite } \\
\text { Grethenius" In Mme. B. de } \\
\text { Khitrowo, Itinéraires } \\
\text { Russes en Orien }\end{array}$ & 1400 & Hac yolculuğu \\
\hline $\begin{array}{l}\text { Ruy Gonzóles de Clavijo } \\
\text { (öl. 1412) }\end{array}$ & $\begin{array}{l}\text { Kastilyalı (İspanya) } \\
\text { seyyah, yazar ve } \\
\text { Papalık elçisi }\end{array}$ & $\begin{array}{l}\text { Embâjada a Tamor Lân } \\
\text { Narrative of the Embassy of } \\
\text { Ruy Gonzalez de Clavijo to } \\
\text { the Court of Timour at } \\
\text { Samarcand AD 1403-6 }\end{array}$ & $1403-1406$ & Anadolu ve Ota Asya \\
\hline $\begin{array}{l}\text { Zheng He/Ho Cheng } \\
\text { (1371-1433) }\end{array}$ & $\begin{array}{l}\text { Müslüman kökenli } \\
\text { hadım Çin Amirali }\end{array}$ & 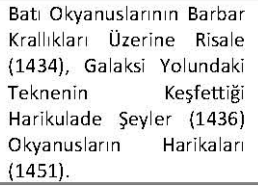 & $1405-1433$ & $\begin{array}{l}\text { Hint Okyanusu ve Doğu } \\
\text { Afrika'da 30'a yakın } \\
\text { krallık }\end{array}$ \\
\hline $\begin{array}{l}\text { Margery Kempe } \\
\text { (1373-1438) }\end{array}$ & $\begin{array}{ll}\text { İngiliz } & \text { Hristiyan } \\
\text { gizemci } & \end{array}$ & $\begin{array}{l}\text { The Book of Margery } \\
\text { Kempe }\end{array}$ & $1413-1415$ & $\begin{array}{l}\text { Kutsal yerlere giden } \\
\text { yollar }\end{array}$ \\
\hline $\begin{array}{l}\text { Christoforo } \\
\text { Buondelmonti } \\
\text { (1385-1430) }\end{array}$ & $\begin{array}{l}\text { Floransalı gezgin ve } \\
\text { papaz }\end{array}$ & Liber Insularum Arcipelagi & $1415-1430$ & $\begin{array}{l}\text { Rodos, İstanbul, } \\
\text { İstanbul haritas। }\end{array}$ \\
\hline $\begin{array}{l}\text { Ciriaco de Pizzicolli (1391- } \\
\text { 1453) }\end{array}$ & $\begin{array}{l}\text { Ankonalı (İtalyan) } \\
\text { tüccar ve hümanist, } \\
\text { arkeologların babası }\end{array}$ & $\begin{array}{l}\text { Cyriac of Ancona: Later } \\
\text { Travels }\end{array}$ & $1418-1447$ & $\begin{array}{lr}\text { Edirne, İstanbul, } \\
\text { Marmara Denizi, Kuzey } \\
\text { Ege, Kiklad Adaları, Girit, } \\
\text { Sakı Adas, Milet, } \\
\text { Midilli, r Mora } \\
\text { Yarımadası, } \\
\text { Ayasofya, Epir } \\
\begin{array}{l}\text { Akropolisi, Delfi } \\
\text { İzsehrir }\end{array} \\
\end{array}$ \\
\hline $\begin{array}{l}\text { Glyôseddin Muhammed } \\
\text { Nakkaş-1 Tebrizî } \\
\text { (14-15. yüzyil) }\end{array}$ & $\begin{array}{lr}\text { Timurlu } & \text { Devleti } \\
\text { hükümdarı Şahruh'un } \\
1419-1420 \text { 'de } & \text { Çin'e } \\
\text { gönderdiğ̈i } & \text { elçilik } \\
\text { heyetinde üye } & \\
\end{array}$ & $\begin{array}{l}\text { Hittây Sefâretnâmesi veya } \\
\text { 'Acâ’ibü'l-lețâ'if. }\end{array}$ & $1419-1420$ & $\begin{array}{l}\text { Çin ( } \\
\text { Farsça resmî elçi } \\
\text { seyahatname) }\end{array}$ \\
\hline Zosima & $\begin{array}{l}\text { Rus diyakoz (yardımc। } \\
\text { keşiş) }\end{array}$ & $\begin{array}{l}\text { Vie \& pèlerinage du diacre } \\
\text { Zosime" }\end{array}$ & $1419-1422$ & Hac yolculuğu \\
\hline John Poloner & $\begin{array}{l}\text { Seyyah, hacı ve din } \\
\text { adam। }\end{array}$ & $\begin{array}{l}\text { Description of the Holy } \\
\text { Land (c. 1421), based on } \\
\text { the translation of Aubrey } \\
\text { Stewart from the Tobler } \\
\text { text. London, } 1894 \text {. }\end{array}$ & 1421 & $\begin{array}{l}\text { Kutsal Topraklar ve } \\
\text { Misir }\end{array}$ \\
\hline $\begin{array}{lll}\text { Bertrandon } & \text { de } & \text { la } \\
\text { Broquière } & & \\
\text { (1400-1459) } & & \end{array}$ & $\begin{array}{l}\text { Fransız ajan, hacl ve } \\
\text { seyyah }\end{array}$ & $\begin{array}{l}\text { The Travels of Bertrandon } \\
\text { de la Brocquiere, } \\
\text { Counsellor \& First Esquire- } \\
\text { Carver to Philippe le Bon, } \\
\text { Duke of Burgundy, to } \\
\text { Palestine, and his Return } \\
\text { from Jerusalem Overland } \\
\text { to France during the Years } \\
1432 \& 1433\end{array}$ & $1432-1433$ & $\begin{array}{lr}\text { Kutsal } & \text { topraklar, } \\
\text { Osmanlı } & \text { sınırları, } \\
\text { Anadolu vd. } & \end{array}$ \\
\hline $\begin{array}{l}\text { Pero Tafur } \\
\text { (1410-1487) }\end{array}$ & İspanyol seyvah & $\begin{array}{l}\text { Andanças é viajes de Pero } \\
\text { Tafur por diversas pares del } \\
\text { mundo avidos } \\
\text { Travels and Adventures, } \\
1435-1439 \\
\text { Pero Tafur Seyahatnamesi }\end{array}$ & $1435-1439$ & $\begin{array}{l}\text { Kudüs'e hac, Misır, } \\
\text { İstanbul, } \\
\text { Trabzon, Kefe, Burne; } \\
\text { vd. }\end{array}$ \\
\hline $\begin{array}{l}\text { Siraceddin } \\
\text { (öl. 1457) }\end{array}$ & Müslüman coğrafyacı & $\begin{array}{l}\text { Harîdetü'l-'acââib ve } \\
\text { ferî́detü'l-garâ'ib }\end{array}$ & 1450 & $\begin{array}{l}\text { Coğrafi bölgeler, dağlar, } \\
\text { nehirler, bitkiler, } \\
\text { hayvanlar, madenler }\end{array}$ \\
\hline
\end{tabular}

